\title{
Using bats as surrogates to effectively target global hotspots for subterranean conservation and monitoring
}

Krizler C. Tanalgo ( $\nabla$ tkrizler@gmail.com )

Landscape Ecology Group, Center for Integrative Conservation, Xishuangbanna Tropical Botanical Garden, Chinese Academy of Sciences, Yunnan, P.R. China https://orcid.org/0000-0003-4140-336X Hernani Oliveira

Department of Zoology, Federal University of Paraná, Curitiba, PR, Brazil https://orcid.org/0000-00017040-8317

Alice C. Hughes ( $\nabla$ ach_conservation2@hotmail.com )

Landscape Ecology Group, Center for Integrative Conservation, Xishuangbanna Tropical Botanical Garden, Chinese Academy of Sciences, Yunnan, P.R. China https://orcid.org/0000-0002-0675-7552

\section{Research Article}

Keywords: Bioindicators, Evolutionary Distinctiveness, Extinction risks, Island endemism, Subterranean habitats.

Posted Date: November 3rd, 2021

DOl: https://doi.org/10.21203/rs.3.rs-492875/v3

License: (c) (1) This work is licensed under a Creative Commons Attribution 4.0 International License. Read Full License

Additional Declarations: There is NO Competing Interest.

Version of Record: A version of this preprint was published at Science of The Total Environment on October 1st, 2022. See the published version at https://doi.org/10.1016/j.scitotenv.2022.156909. 


\section{Using bats as surrogates to effectively target global hotspots for}

2 subterranean conservation and monitoring

4 Krizler C. Tanalgo ${ }^{1,2,3,4,5 *}$, Hernani F.M. Oliveira ${ }^{6}$, Alice Catherine Hughes ${ }^{1,2,3 *}$

$5{ }^{1}$ Landscape Ecology Group, Center for Integrative Conservation, Xishuangbanna

6 Tropical Botanical Garden, Chinese Academy of Sciences, Yunnan, P.R. China

$7{ }^{2}$ Center for Conservation Biology, Core Botanical Garden, Chinese Academy of Sciences,

8 Yunnan, P.R. China

$9{ }^{3}$ International College of the University Chinese Academy of Sciences, Beijing, P.R.

10 China

$11{ }^{4}$ Zukunftskolleg, University of Konstanz, Universitätsstrasse 10, Baden-Württemberg,

12 Konstanz, Germany

$13{ }^{5}$ Department of Biological Sciences, College of Science and Mathematics, University of

14 Southern Mindanao, Kabacan, North Cotabato, Philippines

$15{ }^{6}$ Department of Zoology, Federal University of Paraná, Curitiba, PR, Brazil

16 *Correspondence: tkrizler@gmail.com (K.C.T.), ach conservation2@hotmail.com

17 (A.C.H.) 
Using bats as surrogates to effectively target global hotspots for subterranean conservation and monitoring

Highlights

- As the second-largest mammal taxa bats provide important ecosystem services and are keystone to cave ecosystems.

- Almost half of the global bats are dependent on caves and subterranean habitats.

- We include 679 bats species and 1930 caves from 46 countries to assay patterns of vulnerability and diversity of subterranean habitats across the world.

- Up to $28 \%$ of caves are of high priority.

- Of high priority caves $87.5 \%$ are threatened, and particularly in the tropics (15\%).

\section{Graphical Abstract}
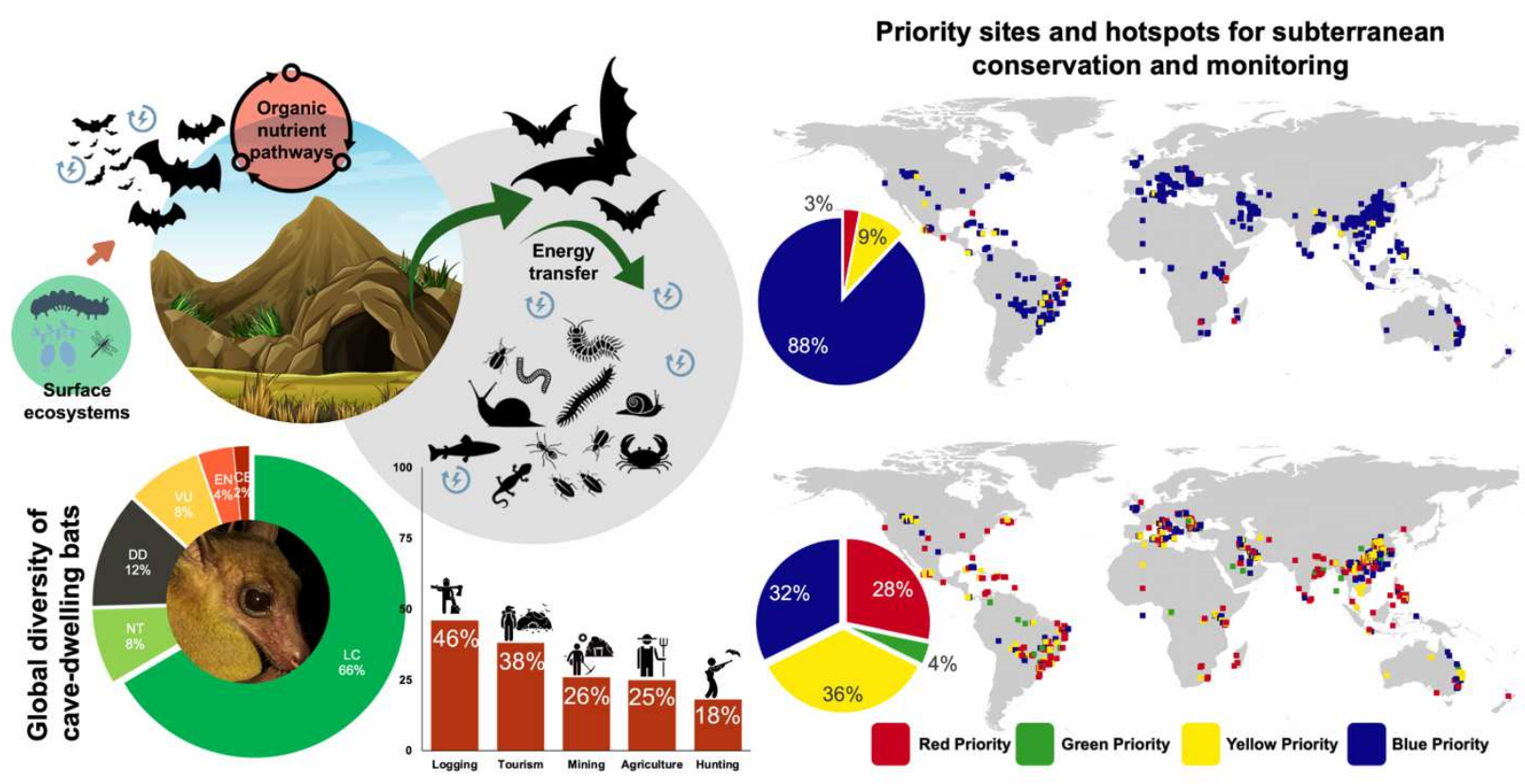


\section{Abstract}

Research and media attention is disproportionately focused on taxa and

48 ecosystems perceived as charismatic, while other equally diverse systems such as caves

49 and subterranean ecosystems are often neglected in biodiversity assessments and

50 prioritisations. Yet these more challenging systems are also vulnerable, with karsts for

51 example losing around $6 \%$ of their area each year, highlighting the urgent need for

52 protection, especially as up to $90 \%$ of cave endemic species may be undescribed. Bats

53 are keystone to cave ecosystems making them potential surrogates to understand cave

54 diversity patterns and identify conservation priorities. On a global scale, almost half (48\%)

55 known bat species use caves for parts of their life histories, with $32 \%$ endemic to a single

56 country, and $15 \%$ currently threatened. We combined global analysis of cave bats from

57 the IUCN spatial data with site specific analysis of 1930 bat caves from 46 countries to

58 develop global priorities for the conservation of the most vulnerable cave ecosystems.

59 Globally, $28 \%$ of caves showed high diversity and were highly threatened and $4 \%$ had

60 high diversity but not currently threatened. Amongst regions, the highest concentration of

61 conservation priority caves was in the Palearctic and tropical regions (except the

62 Afrotropics, which requires more intensive data sampling). Our results further highlight

63 the importance of prioritising bat caves by incorporating locally collected data, and

64 optimising parameter selection (i.e., appropriate landscape features and threats). Finally,

65 to protect and conserve these ecosystems it is crucial that we use frameworks such as

66 this to identify priorities in species and habitat-level, and map vulnerable habitats with the

67 highest biodiversity and distinctiveness. 
68 Keywords: Bioindicators, Evolutionary Distinctiveness, Extinction risks, Island

69 endemism, Subterranean habitats.

\section{Introduction}

We are currently facing the sixth mass extinction, with a higher rate of extinction

72 than at any time since former mass extinctions millions of years ago (Vos et al., 2015).

73 Global biodiversity is threatened by a variety of drivers, and understanding these is critical

74 to determining effective conservation measures in different systems and scales (Ripple

75 et al., 2017). Appropriate evidence-based strategies are essential to optimise the

76 implementation and effectiveness of conservation (Ceballos et al., 2015; Pimm et al.,

77 2014). Various methods and frameworks have been developed to prioritise taxa and their

78 habitats for conservation such as habitat prioritisation and zoning (Conenna et al., 2017;

79 Hernández-Quiroz et al., 2018; Wintle et al., 2019), but many countries may have limited

80 access to such data or resources to effectively implement conservation (Chandra and

81 Idrisova, 2011). Priorities should be matched with future targets and effort allocation to

82 support reaching such targets and ensure that species and their ecosystems are well

83 protected (Arponen, 2012; Groves et al., 2002; Hughes, 2017; Sutherland et al., 2019).

84 However, many species lack the data needed for effective priorities to be developed, and

85 even fewer receive adequate levels of attention (Dolman et al., 2012; Halpern et al.,

86 2006). Yet, as much as conservation scientists try to address the most pressing

87 challenges in global biodiversity conservation, many taxa and their associated habitats

88 are overlooked (Clark and May, 2002). Whilst approaches such as the IUCN Red List of

89 ecosystems, and the new ecosystem typology goes some-way enabling proactive

90 targeting of ecosystems, including those with high numbers of endemic species, they may 
91 overlook certain types of habitats, particularly those which require significant expertise

92 and may be challenging to collate data from (Keith et al., 2015).

93 Human activities have already transformed at least $70 \%$ of terrestrial ecosystems

94 to support human populations (Ellis et al., 2013). Modern combined approaches and

95 technologies are applied to understand environmental processes and threats on above-

96 ground surface ecosystems (e.g., forest ecosystems) which can easily be mapped with

97 remote sensing (Rose et al., 2015). Yet most subterranean habitats including caves are

98 challenging to map, and have frequently been overlooked and neglected in prioritisation

99 (Mammola et al., 2019a; McClure et al., 2020; Sánchez-Fernández et al., 2021). This

100 becomes a barrier to research leaving other habitats and the species dependent on them

101 such as bats understudied and under-protected (Cardinale et al., 2012). The lack of

102 research necessary to understand the unique adaptations and interactions in these

103 systems further challenged subterranean research, which not only prevents cave taxa

104 from garnering public attention, but the special skills needed to study many cave taxa

105 further add to the lack of existing efforts. Cave ecosystems host a variety of highly

106 adapted and sensitive organisms, many of which are cave obligates and dependent on

107 bat guano for nutrients (Deharveng and Bedos, 2018; Ferreira, 2019; Furey and Racey,

108 2016; Monro et al., 2018a; Simon, 2019), and these studies show that guano is the main

109 source of nutrition in most of these systems. Some cave systems have relatively high

110 endemism and up to $90 \%$ of species in a single cave may be undescribed (Monro et al.,

111 2018b; Whitten, 2009), meaning many thousands of species remain undescribed and

112 potentially at risk. However, most conservation projects and funds are focused on taxa or 
113 habitats generally viewed as charismatic (Ford et al., 2017), but neglect fragile

114 ecosystems with higher endemism such as cave ecosystems (Mammola et al., 2019a).

115 Because measuring the entire cave biota is challenging and costly, biodiversity

116 surrogates such as umbrella species can be used to guide targeting of conservation for

117 large cave communities (Lewandowski et al., 2010; Mammola et al., 2019b; Margules et

118 al., 2002). Bats make up the second-largest group of mammals with over 1400 described

119 species distributed across almost all biomes (Burgin et al., 2018; Furey and Racey, 2016).

120 Within subterranean ecosystems, bats are keystone species by bringing nutrients within

121 the cave in the form of their guano and excreta after foraging in surrounding areas, thus

122 providing the basic source of nutrients in these largely lightless zones where the inability

123 for photosynthesis within the system makes this form of nutrient-transfer critical (Cunha

124 et al., 2020; Ferreira, 2019). This function makes bats the ideal ecological indicators and

125 conservation surrogates to inform ecosystem health and priorities to safeguard these

126 systems (Furey and Racey, 2016; Medellin et al., 2017; Tanalgo et al., 2018). Threats to

127 cave-bat populations from habitat loss and degradation, hunting and other factors

128 highlight the need for better methods to develop effective conservation priorities (De

129 Oliveira et al., 2018; Frick et al., 2019; Furey and Racey, 2016) but a standardised

130 approach to identify priorities for action to safeguard these systems does not yet exist,

131 hindering larger-scale prioritisation to protect cave systems and their dependant diversity.

132 Subterranean ecosystems are pervasively threatened by both immediate threats

133 to the caves themselves, and modifications of the surrounding environment (Phelps et

134 al., 2016; Tanalgo et al., 2018). Bats are conspicuous in caves, yet large colony sizes

135 mean that single site impacts can have major consequences on populations especially 
136 for locally endemic species (Frick et al., 2019; Sagot and Chaverri, 2015). In addition to

137 the relatively low reproductive rate in bats that jeopardizes rapid population recovery from

138 loss and declines (Barclay et al., 2004), bats receive little public support and funding

139 compared to other large mammals (Fleming and Bateman, 2016). Many caves and karst

140 habitats are under-protected, for example, only around $13 \%$ of the approximately 800,000

$141 \mathrm{~km}^{2}$ of tropical Southeast Asian karsts are within protected areas (Day and Urich, 2000).

142 Unprotected karst is especially susceptible to human activities and destruction, for

143 example in Southeast Asia the average loss is around $5.7 \%$ of the area annually due to

144 mineral mining (Clements et al., 2006; Hughes, 2017; Liew et al., 2016). This loss of bat

145 cave habitats is coupled with unregulated hunting and tourism, and loss of foraging

146 habitat; therefore understanding the impacts of these factors on the population status of

147 bats and biotically important caves are urgently needed (Furey and Racey, 2016; Sedlock

148 et al., 2014; Tanalgo et al., 2018; Torres-Flores and Santos-Mreno, 2017). It is estimated

149 that at least $50 \%$ of global bat species rely at least partially upon caves (Furey and Racey,

150 2016) but the degree of threat to bat cave communities and prioritisation has never been

151 analysed on a global scale (Tanalgo et al., 2018). Understanding only species

152 distributions, and their extinction risks cannot ensure the protection of all species. The

153 identification of key spatial areas (e.g., a high number of threatened species and

154 endemism levels) that require protection will enable conservation biologists to develop

155 balanced priorities to inform appropriate protection measures. This study is the first

156 extensive study to explore the global diversity patterns and extinction risk of cave-dwelling

157 bats and using this information to create an index to guide effective priority making. 
Here we developed a framework to understand the species-specific and habitat

159 priorities for cave-dwelling bats to identify hotspots for subterranean conservation by

160 integrating different facets of biotic importance and risks across different scales. First, we

161 examined the global (i) patterns of diversity, distribution, and extinction risks of cave-

162 dwelling bats, and (ii) distribution of species threats. Second, we mapped the broad-scale

163 and fine-scale priorities of bat caves based on cave biotic potential and vulnerability to

164 threat. We assess gaps in species information, which is especially important for targeting

165 appropriate conservation measures in karst environments, which represent one of the

166 most challenging ecosystems for assessment.

\section{Materials and methods}

168 Data source and bat species assessment

We sampled global cave-dwelling bats from two databases, the IUCN Red list ( $v$.

170 2020.1) and the DarkCideS ( $v$ 1.0), a global dataset for cave-dwelling bats, including all

171 species that occur, use, roost, or hibernate in caves and underground habitats for any

172 part of their life histories (Data S1-3). All species names were curated and updated using

173 the Bats of the World: A taxonomic and geographic database (Simmons and Cirranello,

174 2020). We included species-specific information including species taxonomy, endemism

175 at geopolitical and biogeographical scales, species range and distributions, conservation

176 status, population trends, ecological traits, and threatening processes. The habitat

177 breadth was determined according to the number of habitats a species occurs (Etard et

178 al., 2020). We used the weighted habitat breadth (\%) values in the final analyses. Species

179 were then classified based on island endemism and country endemism. Whilst country

180 endemism is not strictly an ecological indicator, it is nonetheless useful as if a species is 
181 only present in a single country, then the survival of that species is also subject to

182 strictures of a single country, which increases vulnerability if protection measures are not

183 in place. We then compared the species recorded between the IUCN Red list and the

184 DarkCideS 1.0 to determine gaps in species assessed and cave locality data.

\section{Species diversity and distributions}

Using IUCN data, we calculated geopolitical (e.g., country or continental) species

187 richness based on where the species occurs (including native, extant, resident, possibly

188 extinct or migrant classifications by the IUCN). Second, we analysed and defined

189 endemism in two ways: geopolitical endemism (i.e., a country endemic) if the species

190 occurred only in a single sovereign country (Ceballos and Ehrlich, 2002), and island

191 endemism was classified as island-restricted or predominantly mainland (Faurby et al.,

192 2018). Species conservation status was assessed according to the IUCN Red list criteria

193 and were then simplified to obtained binary extinction risk: "Threatened" (e.g., Vulnerable,

194 Endangered, and Critically Endangered) and "Nonthreatened" (e.g., Least Concern, Near

195 Threatened). While Data Deficient (DD) species were treated as threatened as they may

196 face higher or similar threats, hence a lack of data for formal classification (Bland et al.,

197 2015; Tanalgo et al., 2018; Welch and Beaulieu, 2018). We compared patterns of species

198 diversity across biogeographical realms (Olson et al., 2001; Olson and Dinerstein, 1998)

199 (e.g., Indomalayan, Austral-Oceania, Afrotropical, Neotropical, Palearctic, and Nearctic).

200 Chi-squared test $\left(\chi^{2}\right)$ of association was then used to assess the relationship in species 201 geopolitical endemism, island endemism, conservation status, and population status.

202 We defined country species richness and endemism using simple coherent metrics

203 which are comprehensible for national or regional level conservation and policymaking 
204 (Amori et al., 2011). Using Kendall's $T$ B, we explored the relationships between (1) 205 country estimated species richness, (ii) \% endemic species, and (iii) \% threatened to 206 country land area $\left(\mathrm{km}^{2}\right)$.

\section{IUCN-based species extinction risk}

The IUCN bat data are imperfect, and many species lack updated assessments,

209 using the available data we estimated the extinction risks for different groups and species

210 attributes. Following (Hoffmann et al., 2010; Richman et al., 2015) we estimated the

211 proportion of threatened species across biogeographical realms, species endemism (e.g.,

212 geopolitical and island), population trends, trophic levels, and families. We calculated the

213 proportion of species vulnerable to extinction ( $\hat{p}$ extinction) based on the proportion of

214 threatened species as

215

$$
\hat{p} \text { extinction }=\left(N^{\circ} \text { threatened }\right) /\left(N^{\circ} \text { species }-D D \text { species }\right)
$$

216 where $N^{\circ}$ threatened is the number of threatened species assessed as Vulnerable (VU),

217 Endangered (EN), and Critically Endangered (CE), $N^{\circ}$ species is the total number of species,

218 and $D D$ is the number of Data Deficient species, assuming that $D D$ species will have a

219 similar extinction risk as of other threatened categories as they may face similar or higher

220 threats than those that are non-Data Deficient species (Richman et al., 2015; Tanalgo et

221 al., 2018). We then calculated the lower estimate $\left(\hat{p}\right.$ extinction_lower $=N^{o}$ threatened $/ N^{o}$ species $)$

222 with an assumption that $D D$ species are categorised as non-threatened and upper

223 estimates ( $\hat{p}$ extinction_upper $=N^{o}$ threatened $+D D / N^{o}$ species $)$ with the assumption that $D D$ is

224 threatened. 
Using a Generalized Linear Model (GLM) we determined the predictors of species

226 extinction risk (threatened vs. nonthreatened) for global species and within each

227 suborder, Yinpterochiroptera and Yangochiroptera. We used a total of ten explanatory

228 variables which included geographical variables (geographical range, island endemism,

229 and geopolitical endemism), biological variables (adult body mass $\left(\mathrm{kg}, \log _{10}\right)$ (Faurby et

230 al., 2018), generation length (Pacifici et al., 2013), forest dependency (yes or no based

231 on the IUCN database), weighted habitat breadth (\%), and trophic group). We used the

232 Level-2 habitat data classification from IUCN (2020) that is based on suitable or important

233 habitats for species (Etard et al., 2020). Weighted habitat breadth was calculated based

234 on the number of habitat species used divided by all other habitats. For the trophic groups,

235 we grouped species as frugi-nectarivorous for all species that forage on plant-based

236 resources (e.g., frugivores and nectarivores). Species that forage on animal resources

237 (e.g., insectivorous, sanguivorous, species feeding on vertebrates) were grouped as

238 carnivores, while species that forage on both plant and animal resources were grouped

239 into omnivores. Our last group of explanatory variables includes the species threat index.

\section{Mapping and quantifying threats}

We analysed threats in three different levels: species, cave-site, and country-level.

242 First, we analysed threats per species based on the simplified expert-based IUCN Red

243 list. We modified the threat nomenclature by Salafsky et al. (2008) as it does not

244 completely reflect all threats in bat cave habitats. The Direct threats ( $\left.T_{\text {dir }}\right)$ refer to the

245 threats or risks that are directly within or occurring in the cave systems that have

246 immediate and perceivable impacts on population change or species behaviour. This

247 threat includes direct human impacts and the use of caves such as harvesting bats, 
248 tourism, and mining activities. The Indirect threats ( $\left.T_{\text {ind }}\right)$ refer to the threats outside or 249 within cave proximity, which impacts to population is secondary or non-immediate but 250 detrimental such as deforestation, agriculture, and urbanisation. Lastly, Natural threats 251 ( $\left.T_{\text {nat }}\right)$ refers to threats that are natural in origin that may occur and impact directly or 252 indirectly in the population such as disease and stochastic in nature. We developed the 253 Species Threat Index (STI), which is calculated from the quotient of the sum of species 254 absolute threat ( $\left.T_{\text {dir, ind, nat }}\right)$ and the number of threats assessed $\left(\mathrm{N}^{\circ} \mathrm{T}\right)$. We compared $S T I$ 255 (STI dir, ind, nat) across the biogeographical realm, endemism, conservation status, and 256 population trend using a non-parametric Kruskal-Wallis test.

$$
\left(S T I_{\text {species }}=\Sigma T / N^{\circ} T\right)
$$

We constructed a separate generalized linear model (GLMs) with a binomial 259 distribution (logit link function) in JAMOVI version 2, using GAMLj module (Gallucci, 2019) 260 to understand the link between species traits to a certain threatening process. We used 261 adult body mass $\left(\mathrm{g}, \log _{10}\right)$, geographical range $\left(\log _{10}\right)$ and trophic levels as the predictor 262 variable and threat status (threatened or not threatened) as response variable (Atwood 263 et al., 2020). We only modelled threatening processes that impacted at least $10 \%$ of the 264 cave-dwelling bats.

265 Second, we used remotely sensed data to measure cave vulnerability to threats. 266 For landscape features, we included canopy cover height (Simard et al., 2011), tree 267 density (Crowther et al., 2015), distance to bodies of water (Yamazaki et al., 2015), bare 268 ground cover change (Song et al., 2018), short vegetation cover change (Song et al., 269 2018), tall tree cover change (Song et al., 2018) and for vulnerabilities we include distance 270 to urban areas (Song et al., 2018), distance to roads (Meijer et al., 2018), mine density 
271 (Labay et al., 2017), night light (Earth at Night, 2019), relative pesticide exposure (Maggi

272 et al., 2019), and population density (Hughes, 2019; SEDAC, 2020). We then assessed

273 the correlation between landscape variables to cave species biotic scores and the extent

274 was compared across biogeographical realms.

275 Third, we ranked each country based on total species richness, the proportion of

276 both threatened and endemic species and its concordance to sociodemographic and

277 environmental indicators as rudimentary indicators of a country's resources to

278 representing its capacity to monitor and protect its species and environment (e.g.,

279 Convention of Biological Diversity) (Amori et al., 2011; McGeoch et al., 2010). In our

280 analyses, we used percent forest cover (The World Bank, 2020) as a proxy for habitat

281 intactness and quality per country, with the assumption that caves surrounded by intact

282 forest are more protected and least vulnerable to intrusions (Cajaiba et al., 2021; Phelps

283 et al., 2018; Tanalgo et al., 2018). While we used country cement production (TTM*1000)

284 (Index Mundi, 2020) as a proxy to species susceptibility to direct threats assuming that in

285 areas with higher cement production species are more prone to habitat loss and direct

286 disturbances (Liew et al., 2016; Tanalgo et al., 2018). We applied Kendall's $\tau$ B to test for

287 the ranked-concordance in (i) country-level species richness ( $\log 10)$, (ii) \% endemism,

288 (iii) \% threatened species, (iv) percent forest cover (\%, log 10) (iii) socioeconomic 289 indicators: GDP per capita (log 10), country cement production (TTM). We mapped and 290 visualised estimated species richness, endemism, and threatened species using QGIS 291 version 3.14

292 Global Bat Cave Vulnerability Index (BCVI-G) 
Using the global 'Bat Cave Vulnerability Index'(Tanalgo et al., 2018) (hereafter

294 'BCVI-G'), we assessed habitat-level priorities of pooled bat caves (Data S3). The

295 prioritisation index is based on two integrated sub-indices representing cave biotic

296 potential and vulnerability. The first component of the index is the cave Biotic Potential

297 (BP), which analyse, and measure bat cave biological values based on bat species

298 richness and attribute status. The second component is the cave Biotic Vulnerability (BV)

299 measures the cave landscape feature and vulnerability to threats. Using the index, we

300 mapped and constructed broad-scale and fine-scale cave priorities representing biome

301 and site-level analyses respectively. We modified the first version of BCVI to address

302 some of its limitations for incomplete or unstandardised data and make it relevant for a

303 comparative global-scale prioritisation scheme for the new BCVI-G.

$$
B C V I-G=B P \times B V
$$

\section{Cave Biotic Potential (BP)}

We excluded data from population estimates to minimise bias from the missing

307 and unstandardised assessments in caves datasets, and which is a component of the

308 first BCVI and can be used at more local scales. Second, in addition to species attribute

309 status scoring (conservation status, population trends, country endemism, and island

310 endemism (Table 1), we incorporated evolutionary units including evolutionary

311 distinctiveness (ED, based on EDGE score (Isaac et al., 2007)) and corrected weighted

312 endemism (CWE) to factor the cave biotic potential (BP). We calculated corrected

313 weighted endemism (CWE) (Crisp et al., 2001; Laffan and Crisp, 2003) by dividing

314 weighted endemism (WE) by the total cave species richness (e.g., absolute counts of 
315 species). This measures the proportion of bat species in a cave site. We then calculated

316 BP using the equation

$$
\mathrm{BP}_{\text {cave } \mathrm{x}}=\sum S_{\text {cave } \mathrm{x}} / \operatorname{Max} . \sum S_{\text {cave } \mathrm{y}}
$$

318 where cave BP is the calculated quotient of the sum of cave species attributes scores $(\Sigma$

$319 S_{\text {cave } \mathrm{x}}$ ) and the highest maximum ( $\Sigma S_{\text {cave } \mathrm{y}}$ ) sum of species attribute scores from all 320 sampled caves (cave y) within the single site or the entire biome. Where $S_{\text {cave } x}$ is the sum

321 score of $\mathrm{n}^{\text {th }}$ bat cave species evolutionary distinctiveness (ED), corrected weighted

322 endemism $(\times 100)(\mathrm{CWE})$, conservation status (Cons), population trends (Pops), country 323 endemism (E), and island endemism (IsI).

$324 S_{\text {cave } \mathrm{x}}=\Sigma$ Species $1(\mathrm{ED}+\mathrm{CWE}(\times 100)+$ Cons + Pops $+E)+$ Species $2(\mathrm{ED}+\mathrm{CWE}$

$$
(\times 100)+\text { Cons }+ \text { Pops }+E)+ \text { Species } 3(\text { ED }+ \text { CWE }(\times 100)+\text { Cons }+ \text { Pops }+E)
$$

The $\mathrm{BP}_{\text {cave }}$ index score ranges from 0.00 to 1.00 , with values near 1.00 indicates

327 higher cave biotic potential and scaled to four levels of priority (Table 2).

328 Table 1. Scoring of species attributes for calculation of cave Biotic Potential (Bp) based 329 on species Population trends (pops), Conservation status (cons), Country endemism

\begin{tabular}{|c|c|c|c|c|c|c|c|}
\hline pops & score & cons & score & $E$ & score & $|\mathbf{s}|$ & score \\
\hline Increasing & 2.5 & Least concern & 2 & $\begin{array}{l}\text { Non- } \\
\text { endemic }\end{array}$ & 5 & $\begin{array}{l}\text { Non- } \\
\text { islandi } \\
\text { c }\end{array}$ & 5 \\
\hline Stable & 5 & $\begin{array}{l}\text { Near } \\
\text { Threatened }\end{array}$ & 4 & Endemic & 10 & $\begin{array}{l}\text { Islandi } \\
\mathrm{C}\end{array}$ & 10 \\
\hline Unknown & 7.5 & Vulnerable & 6 & & & & \\
\hline Decreasing & 10 & $\begin{array}{l}\text { Endangered } \\
\text { Critically } \\
\text { endangered/D } \\
\text { ata deficient }\end{array}$ & $\begin{array}{l}8 \\
10\end{array}$ & & & & \\
\hline
\end{tabular}
$330(\mathrm{E})$, and Island endemism (IsI). 
333 Table 2. Cave Biotic Potential (Bp) priority status and description of the probable

334 scenario. The interpretation of the probable scenario was based on Tanalgo et al. 2018.

\begin{tabular}{|c|c|c|}
\hline $\begin{array}{l}\text { Bp cave } / \text { /BP } \\
\text { cave } \text { max }\end{array}$ & $\begin{array}{c}\text { BP } \\
\text { status }\end{array}$ & Probable relative scenario \\
\hline $0.00-0.24$ & Level 4 & $\begin{array}{l}\text { Contain the lowest species richness, lowest sum } \\
\text { of species attributes, with the absence of } \\
\text { threatened and endemic species. Probably no } \\
\text { rare species in the cave. }\end{array}$ \\
\hline $0.25-0.49$ & Level 3 & $\begin{array}{l}\text { Species richness and the sum of species } \\
\text { attributes may be lower. Threatened and endemic } \\
\text { species may be present. Probably no rare } \\
\text { species in the cave. }\end{array}$ \\
\hline $0.50-0.74$ & Level 2 & $\begin{array}{l}\text { Cave may be high in species richness and sum } \\
\text { species attributes, with the presence of few } \\
\text { endemic and threatened species. Rare species } \\
\text { may potentially present. }\end{array}$ \\
\hline $0.75-1.00$ & Level 1 & $\begin{array}{l}\text { Highly species richness, with highest sum of } \\
\text { species attributes. Several threatened and } \\
\text { endemic species is present. Cave contains the } \\
\text { rarest species. }\end{array}$ \\
\hline
\end{tabular}

The computed cave BP is then complimented with the cave Biotic Vulnerability 338 (BV) to derive the final cave alphanumeric priority based on vulnerability. First, we 339 mapped and measured the extent of geophysical features represented landscape 340 features and threats in a single cave following (Hughes, 2019) using ArcGIS version 10.3

341 (see reference for detailed methods for every landscape feature). Because of the

342 relatedness of landscape features to represent cave vulnerability to threats, we selected

343 representative features to enter in BV calculations: (i) distance to urban area, (ii) distance

344 to roads, (iii) tree density, (iv) canopy cover, (v) mining density, and (vi) distance to bodies

345 of water (for arid biomes). We calculated cave Biotic Vulnerability ( $\mathrm{BV}$ cave) as the quotient

346 of summed scores of $N T$ and the total number of geophysical features assessed $\left(N^{\circ}, N^{\circ}\right.$ $347=5)$. 
349 where $N T\left(N T=T x / T_{\max } \mathrm{y}\right)$ is the score of geophysical or landscape features $(T)$ based

350 on the quotient between the measured extent of geophysical features in a specific cave

351 ( $\mathrm{T} x$ ) divided to the maximum value of measured extent of threats and landscape features

352 in all sampled caves $\left(T_{\max } \mathrm{y}\right)$. The $N$ score ranges from 0.00 to 1.00 and is scaled in four-

353 level range scoring representing cave relative probable scenario (Table 3).

354 Table 3. Scoring system for Biotic Vulnerability (BV) index based on the extend of the 355 landscape features and cave probable relative scenario.

\begin{tabular}{|c|c|c|c|}
\hline $\begin{array}{c}\text { Threat or landscape } \\
\text { features }\end{array}$ & $T x / T_{\max } y$ & $\begin{array}{l}\text { BV } \\
\text { score }\end{array}$ & $\begin{array}{c}\text { Probable relative } \\
\text { scenario (worst to best) }\end{array}$ \\
\hline \multirow[t]{4}{*}{$\begin{array}{l}\text { Distance to } \\
\text { city/urbanisation }\end{array}$} & $0.00-0.24$ & 1 & $\begin{array}{l}\text { Cave site is within or } \\
\text { surrounded by heavy } \\
\text { urbanisation; highly } \\
\text { vulnerable to visitation and } \\
\text { unregulated tourism. }\end{array}$ \\
\hline & $0.25-0.49$ & 2 & \\
\hline & $0.50-0.74$ & 3 & \\
\hline & $0.75-1.00$ & 4 & $\begin{array}{l}\text { Cave is not surrounded by } \\
\text { urbanisation, or very far } \\
\text { any urbanisation. Cave is } \\
\text { probably located in a } \\
\text { pristine area. }\end{array}$ \\
\hline \multirow[t]{3}{*}{ Distance to roads } & $0.00-0.24$ & 1 & $\begin{array}{l}\text { Cave site is accessible by } \\
\text { roads or human trails. } \\
\text { Highly accessible and } \\
\text { vulnerable to visitation and } \\
\text { intrusion. Cave sites with } \\
\text { hyper-population may be } \\
\text { vulnerable to hunting. }\end{array}$ \\
\hline & $0.25-0.49$ & 2 & \\
\hline & $\begin{array}{l}0.50-0.74 \\
0.75-1.00\end{array}$ & $\begin{array}{l}3 \\
4\end{array}$ & $\begin{array}{l}\text { Cave site is inaccessible by } \\
\text { roads or human trails. } \\
\text { Roads may be absent. } \\
\text { Difficult to access by } \\
\text { human visitation. }\end{array}$ \\
\hline Mine density & $0.75-1.00$ & 1 & $\begin{array}{l}\text { Cave site is in a high } \\
\text { mining density area. }\end{array}$ \\
\hline
\end{tabular}


Canopy cover

$\begin{array}{ll}0.50-0.74 & 2 \\ 0.25-0.49 & 3 \\ 0.00-0.24 & 4\end{array}$

$0.00-0.24$

$0.25-0.49$

$0.50-0.74$

$0.75-1.00$

Tree density

$0.00-0.24$

$0.25-0.49$

$0.50-0.74$

$0.75-1.00$
Extensive mineral extraction occurs within the cave site.

Mining is low or probably absent.

1 Cave site is in a more open area. The occurrence of deforestation is probably high. The cave is potentially in an arid environment with low tall tree vegetation. The cave is very exposed and highly vulnerable to human intrusion and other disturbances.

$4 \quad$ Cave is probably in a pristine or robust forested area. Tall tree vegetation is probably high. Foraging grounds for bats are highly available. The cave is probably located in a protected area.

1 Cave site is in a heavily disturbed area.

Deforestation and other surface threats (e.g., mining and urbanisation) may be highly present. The cave site is very exposed and highly vulnerable to population loss.

2

3

$4 \quad$ Cave site occurs in a very pristine and intact forested area. Surface threats may be low or absent. Foraging grounds for bats are highly available. The cave is 
probably covered by

protected areas.

357 Mapping conservation priorities

We aimed to assess the vulnerability of global bat caves based on community level

359 bat data and mappable landscape features and threats (Figure 7). We performed BCVI-

$360 \mathrm{G}$ prioritisation at a number of spatial scales. First, the broad-scale priorities represent

361 biome-dependent analyses. Secondly, we measured at the site-level diversity and

362 vulnerability to encompass the fine-scale prioritisation. Here we set cave priorities at a

363 national scale, with the assumption that priorities should be comparable to guide decision

364 making at any scale. The alphanumeric index derived from BCVI-G is divided into four

365 priority categories (Table 4). We then compared the mean biotic vulnerability (i.e., values

366 range from 1 to 4 , the lower the values the higher the vulnerabilities) versus cave biotic

367 potential status, and then the priorities from both scales across biogeographical realms

368 and biomes using a chi-squared test $\left(\chi^{2}\right)$. We used Pielou's index in PAST - to assess

369 evenness in BCVI-G and priorities between scales.

370 Table 4. Priority scales of caves based on Bat Cave Vulnerability Index-Global (BCVI$371 \mathrm{G})$.

\begin{tabular}{|c|c|c|c|}
\hline BCVI-G & Priority-level & Condition & Potential action \\
\hline $1 \mathrm{~A}, 1 \mathrm{~B}, 2 \mathrm{~A}$ & Red Priority caves & $\begin{array}{l}\text { High diversity and high } \\
\text { threat exposure }\end{array}$ & $\begin{array}{l}\text { Cave needs } \\
\text { immediate action }\end{array}$ \\
\hline $1 \mathrm{D}, 1 \mathrm{C}$ & Green Priority caves & $\begin{array}{l}\text { High diversity, but } \\
\text { threat exposure is } \\
\text { absent }\end{array}$ & $\begin{array}{l}\text { Cave needs } \\
\text { monitoring }\end{array}$ \\
\hline $\begin{array}{l}2 B, 2 C, 2 D \\
3 A, 3 B, 3 C \\
3 D\end{array}$ & Yellow Priority caves & $\begin{array}{l}\text { Under high threat, and } \\
\text { moderate diversity. May } \\
\text { have already lost } \\
\text { species. }\end{array}$ & $\begin{array}{l}\text { Cave needs } \\
\text { intervention or may } \\
\text { no longer be } \\
\text { worthwhile }\end{array}$ \\
\hline
\end{tabular}



$4 \mathrm{~A}, 4 \mathrm{~B}, 4 \mathrm{C}$
$4 \mathrm{D}$
Blue Priority caves
High to low threat, with
very low diversity. May have already lost
Cave not worth attention
species.

373 Results

374 Global diversity and distribution of cave-dwelling bats

375

The IUCN lists a total of $679\left(N_{\text {cave }}=679\right.$ spp./1400 $)$ cave-dwelling species

376 constituting the $48.5 \%$ of described global bat species belonging to all bat families.

377 Vespertilionidae comprised the largest proportion of all cave-dwelling species with 215

378 species ( $\left.\%_{\text {cave }}=32, \%_{\text {global }}=43\right)$, and followed by Phyllostomatidae $\left(N=96, \%_{\text {cave }}=14\right.$,

$379 \%$ global $=45)\left(\right.$ Table S1). Most species are concentrated in the tropical regions $\left(\chi^{2}=205.83\right.$,

$380 d f=5, P<0.0001)$ with $30 \%(N=227$ spp. $)$ of global cave-dwelling bats in the

381 Indomalayan region (Figure 1). At a country level, Indonesia has the highest number of 382 species ( $N=104 \mathrm{spp}$.), followed by China ( $N=98 \mathrm{spp}$. ), and India ( $N=82 \mathrm{spp}$.) (Figure

383 S1; Data S2). In addition, Indonesia ( $N=18$ spp., $\%$ threatened $=17 \%)$, and India $(N=10$

384 spp., $\%$ threatened $=12 \%$ ), were the countries with highest number of threatened species.

385 Unsurprisingly, we found congruence between country land area $\left(\mathrm{km}^{2}\right)$ and estimated 386 species richness $(\tau=0.40, P<0.001), \%$ threatened $(\tau=0.41, P<0.001)$ and $\%$

387 endemism $(\tau=0.19, P<0.001)$.

Globally, $32 \%$ of cave-dwelling bat species were endemic to a single country and $38923 \%$ to small islands. Most of the geopolitically endemic species are classified as 390 threatened $(63.58 \%, N=110 \mathrm{spp}$.) compared to less threatened $(21.74 \%, N=63 \mathrm{spp}$.) $391\left(\chi^{2}=120.50, d f=5, P<0.0001\right)$. The majority of data deficient species $(57 \%, N=47 \mathrm{spp}$. 
392 are country endemic. Moreover, the distribution of island endemic species significantly

393 differed across conservation statuses $\left(\chi^{2}=192, d f=2, P<0.001\right)$. The $77 \%(N=520$

394 spp.) of the species are found on mainland and near-shore islands and $23 \%(N=159$ 395 spp.) are restricted to islands (Figure 1). Unsurprisingly, $75 \%$ of island species are country 396 endemic versus $81 \%$ of the non-endemic occur in mainland areas $\left(\chi^{2}=171, d f=1, P<\right.$

397 0.001). Moreover, the proportion of species in threatened categories within island 398 endemism is higher for island restricted species ( $40 \% ; N=43 \mathrm{spp}$.) compared to mainland 399 species $(21 \% ; N=173$ spp. $)\left(\chi^{2}=35.4, d f=2, P<0.001\right)$.

\section{Patterns of threat and extinction risks}

401 Using the IUCN data, the estimated extinction risks of cave-dwelling bat species $402(\hat{p}$ extinction $=15 \%, 13-25 \%)$ is lower than that of all bat species $(\hat{p}$ extinction $=20 \%, 16-35 \%)$, 403 of which $37 \%$ are in a threatened category and $12 \%$ are data deficient (Figure 2A, Table 404 S2). Extinction risk is relatively higher when compared across sub-orders, families, and 405 trophic groups compared to all species. Moreover, country endemic species $(\hat{p}$ extinction $=$ $40636 \%, 29-50 \%$ ) and species occurring on islands (islandic: $\hat{p}$ extinction $=40 \%, 35-48 \%$ ) are 407 facing exceedingly high extinction risk (Figure 2A, Table S2). Additionally, a strong link 408 between narrow geographic range and species extinction risk can be attributed in all 409 cave-dwelling species $(\beta=-1.94, P<0.001)$ and for both suborder models (Yin: $\beta=-$ 410 2.34, $P<0.001$; Yang: $\beta=-2.02, P<0.001)$. Country endemism $(\beta=-0.67, P=0.013)$

411 and island endemism $(\beta=1.00, P<0.001)$ are also linked to extinction risk globally. But 412 varies within suborders, island endemism could only predict species with a high extinction 413 risk from Yangochiroptera $(\beta=1.17, P<0.001)$ and geopolitical only for 414 Yinpterochiroptera $(\beta=-1.19, P=0.028)$ (Figure 2B, Table S3). Moreover, none of the 
415 biotic variables (trophic level, generation length, and adult body mass) included in the

416 model could predict extinction risk globally and within suborders. Among threat variables,

417 only direct threats showed significant association globally $(\beta=2.221, P=0.008)$ and

418 between suborders (Yin: $\beta=2.84, P=0.043$; Yang: $\beta=2.50, P=0.031$ ) (Figure 2B).

419 Nearly three-quarters $(69 \%, N=466$ spp.) of the cave-dwelling bat species are 420 exposed to various threats according to the IUCN. The proportion of direct (Kruskal-Wallis 421 test: $\chi^{2}=13.02 d f=5, P=0.02$ ) and indirect (Kruskal-Wallis test: $\chi^{2}=30.10, d f=5, P<$ $4220.01)$ threats differed regionally. However, there is a large disparity in the species 423 threatened by natural threats with only $10 \%(N=70 \mathrm{spp}).\left(S T I_{\text {nat }}=1.40\right)$ of the species 424 assessed facing geo-climatic induced threats. (Figure S1, Table S4). Species risks to 425 dominant threats such as agricultural conversion $(\beta=-0.214, P=0.017)$ and deforestation $426(\beta=-0.154, P=0.05)$ were significantly linked to small geographic range. Conversely, 427 species with large geographic ranges were more at risk from pollution $(\beta=0.498, P=$ 428 0.003). Species adult body mass is a strong predictor of species vulnerability for hunting 429 and bushmeat for large species $(\beta=0.845, P<0.001)$. Within trophic levels, omnivores 430 have a significantly higher risk from mining and quarrying compared to frugi-nectarivores $431(\beta=-1.029, P=0.023)$ and carnivores $(\beta=-0.636, P=0.026)$. Frugi-nectarivores are 432 more vulnerable to hunting and harvesting $(\beta=2.256, P=0.001)$, and insectivores to 433 pollution $(\beta=1.483, P=0.044)$ compared to other trophic levels (Figure S2 and Table 434 S5).

435 On a global scale, seven out of twelve variables showed a significant relationship 436 with summed species biotic scores ( $\Sigma S_{\text {cave }}$ ) but none of the landscape features and 437 threat variables showed a strong correlation to diversity (Figure 4A). Tree density, bare 
438 ground cover change, and short vegetation cover change showed a positive correlation

439 with bat cave diversity. Conversely, distance to bodies of water, tall tree loss, nightlight,

440 and population density showed a significant negative correlation though this may in part

441 reflect the challenges of sampling caves in tall, forested areas, but also highlights that

442 recently disturbed areas may be threatened. Furthermore, socioecological variables,

443 GDP per capita, \% forest cover, and cement production as a proxy to assess the

444 vulnerability of geopolitically endemic species showed consistent correlations amongst

445 species diversity attributes (Figure 3C, Data S2).

\section{Habitat priorities for cave-dwelling bats}

447 The degree of evolutionary distinctiveness (ED) constructed on bat cave data 448 significantly differed regionally (Kruskal-Wallis, $\chi^{2}=1615.65, d f=5, P<0.001$ ). The

449 highest ED was in the Neotropical region $\left(E D_{\text {mean }}=11.92\right)$ with the lowest in the Palearctic $450\left(E D_{\text {mean }}=5.54\right)$. Cave weighted endemism is highest in the Austral-Oceania $\left(C W E_{\text {mean }}=\right.$ 451 6.32) consistent with the proportion of species endemism observed in the region (Kruskal452 Wallis, $\chi^{2}=1584.84, d f=5, P<0.01$ ) (Figure 4). Prioritisation at broad and fine scales 453 showed that the majority of cave sites are highly vulnerable to threats (Figure 5A-D). In 454 fine-scale analysis, we found a significant relationship in biotic potential and biotic 455 vulnerability score (Kruskal-Wallis test: $\chi^{2}=14, d f=3, P=0.003$ ). Caves with higher 456 biotic potential are linked to lower vulnerability caves (i.e., cave systems located in 457 relatively pristine ecosystems), while there is a lower biotic potential in caves with higher 458 threats and vulnerability (Kruskal-Wallis test: $\chi^{2}=6.45, d f=3, P=0.092$ ). This pattern is 459 consistent at broad scales, but the relationship was not significant (Kruskal-Wallis test: $\chi^{2}$ 
$460=6.45, d f=3, P=0.092)$ (Figure $5 \mathrm{E}-\mathrm{F}$ ), likely relating to the lack of site-specific data 461 needed.

463 a comparative prioritisation across the biogeographical realm and climate regions (Data 464 S3, Table S6). On a broad scale, $95 \%$ of the caves show high biotic vulnerability (Status 465 A) but $88 \%$ of the caves have a lower biotic potential level (Level 4 ) in contrast to only $1 \%$ 466 with high biotic values (Level 1) (Figure 6A). The integration of two sub-indices within the 467 broad-scale equates to the uneven and high proportion (83\%) of " $4 \mathrm{~A}$ " lower vulnerability 468 index values for overall sampled caves $\left(J^{\prime}=0.378\right)($ Figure $6 A)$. Conversely, fine-scaled 469 BCVI-G analyses showed a more even distribution of indices values $\left(J^{\prime}=0.917\right)$ 470 compared to the broad-scale analyses. At a fine scale, there is an increase at $45 \%$ in the 471 proportion of caves with high biotic potential (Level 1), 14\% at a mid-high level (Level 2),

472 and $41 \%$ of caves had a lower biotic potential (Level 4). Subsequently, an even 473 distribution of biotic vulnerability was also observed with fine-scale BCVI-G, $45 \%$ and $41 \%$ 474 of the caves are in high (Status A) to mid-high (Status B) vulnerability, respectively. 475 Moreover, $10 \%$ of the caves are in the " $1 \mathrm{~A}$ " high vulnerability index. A high proportion of 476 high vulnerability caves occur in tropical realms (Figure $6 \mathrm{~A}$ ). We found a significant 477 difference in the cave vulnerability index in both scales (Broad: $\chi^{2}=8977.87, d f=7, P<$ 478 0.001; Fine: $\left.\chi^{2}=1303.09, d f=15, P<0.001\right)$.

480 Table 5. Comparison of achieved per cent priorities between broad-scale and fine-scale 481 analyses using the Bat Cave Vulnerability Index- Global (BCVI-G). Full data of BCVI-G 482 results and priorities in two scales are in Supplementary Data 3 and Supplementary 483 Table 6. 


\begin{tabular}{lcccr}
\hline Priority-level & Broad-scale & Fine-scale & $\begin{array}{c}\text { Global } \\
\text { average }\end{array}$ & Priority difference \\
\hline Red & $3 \%$ & $28 \%$ & $15 \%$ & $+25 \%$ \\
Green & $0 \%$ & $4 \%$ & $2 \%$ & $+4 \%$ \\
Yellow & $9 \%$ & $36 \%$ & $23 \%$ & $+27 \%$ \\
Blue & $88 \%$ & $32 \%$ & $60 \%$ & $-56 \%$ \\
\hline
\end{tabular}

484

Our analysis of the sampled caves showed that the priority levels of caves are 486 scale-dependent and varied significantly across spatial scales $\left(\chi^{2}=1281.43, d f=3, P<\right.$ 487 0.001) (Figure 6B; Table S6). Caves were classified on the basis of the need for different 488 types of intervention or management based on threat and biotic characteristics, most 489 importantly these include "red caves", which whilst diverse are threatened and in need of 490 intervention, and "green caves" which are also diverse but not currently at risk, whilst 491 "yellow caves" are at an intermediate level in terms of diversity and may need intervention 492 to prevent species loss and allow recovery. On a broad scale, only $3 \%$ of the sampled 493 caves are at "Red Priority", 9\% at "Yellow Priority", and 88\% at "Blue Priority" levels. The 494 low proportion of high priority caves are significantly concentrated in the Neotropical 495 (45\%), Afrotropical (18\%) and Indomalayan (16\%) regions $\left(\chi^{2}=204.20, d f=10, P<\right.$ 496 0.001) (Figure 6B, Table S6). While on a fine scale, there is a significant increase in the 497 proportion and evenness $\left(J^{\prime}=0.395\right)$ of high priority caves compared to broad-scale. Of 498 the sampled caves, $28 \%$ are "Red Priority", 36\% are "Yellow Priority", and $4 \%$ are "Green 499 Priority" caves that host high biotic potential but low vulnerability (Figure 6B, Table 5). 500 The concentration of high priority caves is highest in the Palearctic (30\%) closely followed 501 by Neotropical $(29 \%)$ and Indomalayan $(28 \%)\left(\chi^{2}=73.93, d f=15, P<0.001\right)$. When 502 compared by biomes and climatic regions, the $58 \%$ and $25 \%$ of high priority caves are 
503 concentrated in the tropics and temperate regions respectively $\left(\chi^{2}=56.76, d f=12, P<\right.$

$5040.001)$ (Figure 6B).

505 Discussion

506 Bats and caves in the changing world

507 This is the first study to present the integrative taxonomic and habitat-level

508 conservation priorities for cave-dwelling bats on a global scale. In our previous work

509 (Tanalgo et al., 2018), we developed BVCl for local and community-level applications,

510 including local factors such as population and other site-specific factors. However, whilst

511 such an approach is ideal for a region or country, especially where a single team can

512 inventory all sites, priorities across a broader region require more data that can be collated

513 remotely and can be sourced from multiple teams. Thus the new approach provides an

514 index that can be applied across wide regions, or as here globally, and like the Essential

515 Biodiversity Variables (EBV's) (Jetz et al., 2019) allows remotely sensed data to be

516 integrated with on the ground data to provide a more robust index for prioritisation. Caves

517 and underground habitats are used by almost half $(48.5 \%, N=679 \mathrm{spp}$.) of all bat species,

518 with a large fraction restricted to small ranging islands (23\%) and considered endemic

$519(32 \%)$ or threatened $(25 \%)$. We observed higher extinction risk in species with a narrow

520 geographical range distribution (e.g. island and nationally endemic species), consistent

521 with other studies(Jones et al., 2003; Welch and Beaulieu, 2018). The association of

522 endemism level to extinction risk varies phylogenetically showing that closely related

523 species have a similar association (Jones et al., 2003), island and geopolitical endemism

524 is respectively correlated to suborders Yangochiroptera and Yinpterochiroptera. Whilst

525 cave-dwelling bats are not the sole biological indicators in subterranean ecosystems, their 
526 diversity may offer a relatively cost-effective conservation surrogate for systematic

527 monitoring to protect the vast diversity of cave-dependent species. The patterns of cave

528 bat diversity and distribution are consistent with the patterns observed for global bats, 529 peaking in the tropics and particularly in the Indomalayan, Afrotropical, southern

530 Palearctic, and Neotropical regions (Burgin et al., 2018; Frick et al., 2019). However

531 estimates of diversity and proportion of threatened species are likely to be underestimated

532 due to current taxonomic gaps, large numbers of undescribed cryptic species, and lack

533 of accurate species distributions assessments for global bats (Francis et al., 2010; Murray

534 et al., 2012; Welch and Beaulieu, 2018).

\section{Understanding threats to species and habitats}

536 Direct threats showed a strong link to species extinction risks in all our models.

537 Large colonies in many cave-dwelling bat species make them more vulnerable to direct

538 anthropogenic disturbances such as hunting, harvesting, and unregulated tourism (Sagot

539 and Chaverri, 2015). Large-bodied species are likely vulnerable to hunting and

540 harvesting. The $18 \%$ of cave-dwelling bats are threatened by hunting, largely in parts of

541 the Afrotropical and Indomalayan regions. This represents a large proportion (62\%) of bat

542 species (167 spp.) hunted globally (Mildenstein et al., 2016), and is likely to be an

543 underestimate as hunting in many regions is poorly documented. The high level of hunting

544 and harvesting in the Old-World tropics is primarily driven by subsistence and primarily

545 localised particularly in areas with high levels of poverty and driven by the demand for

546 protein sources, food, and traditional medicine (Cardiff et al., 2009; Goodman, 2006;

547 Mickleburgh et al., 2009). The most frequently hunted species are common and hyper-

548 abundant cave species (e.g., Rousettus amplexicaudatus, Eonycteris spelaea, Eidolon 
549 helvum), which have a smaller portion of their range protected because of their 550 widespread, non-threatened status (Aziz et al., 2021). However, as a consequence of the 551 absence of statuary protection for many common species intensifies hunting and can 552 cause even common and abundant species to become locally or regionally extinct 553 (Tanalgo and Hughes, 2019). Separately, unregulated tourism is a direct threat to $38 \%$ of

554 the cave-dwelling species and unregulated activities may alter cave microclimate and 555 affect sensitive species.

556 Cave-dwelling bats are also at risk from land degradation as a result of 557 deforestation and agricultural conversions (Cajaiba et al., 2021; Jones et al., 2009). Over $55850 \%$ of the species are already losing habitat in close proximity to their roost sites but this 559 may be underestimated as at least $12 \%$ of the species are data deficient and even more 560 species lack updated red list assessments. Disturbed caves in deforested and agricultural

561 lands drive the loss of specialist bats, whereas fewer disturbed caves support high 562 species richness and abundance (Cajaiba et al., 2021). Furthermore, increased 563 deforestation and vegetation removal around cave sites increases the exposure of caves 564 to human intrusion and potentially increases vulnerability to direct threats e.g., hunting 565 and tourism. Additionally, extractive industries of mining and quarrying threaten more than 566 a quarter of cave-dwelling bats, through degradation and destruction of caves and 567 alterations of surface vegetation, which creates barriers that limit species movements and 568 foraging (Theobald et al., 2020). Although our analyses showed that average mining 569 density is higher in the Nearctic region, this largely omits quarrying for limestone (as such 570 maps are rarely available)(Sonter et al., 2018). However, cement export is significantly 571 higher in countries with high cave-bat species richness and high numbers of threatened 
572 species (e.g., in Southern China and throughout mainland Southeast Asia), in part

573 because of the extensive limestone karsts in these regions.

\section{Habitat conservation and priorities}

575 Globally, $3 \%$ to $28 \%$ of bat caves need immediate conservation interventions, 576 while $9 \%$ to $35 \%$ require monitoring due to high diversity, but low risk at present. Overall, 577 the patterns of habitat level priorities are consistent with previous global studies

578 comparing the value of broad- and fine-scale analyses in identifying priorities. The broad-

579 scale analysis provides an overview of patterns to guide where further focus and fine-

580 scale prioritisation is needed. There is a slight overlap in priorities between scales such

581 as some high priority caves from the broad-scale analysis are the same in the fine-scale

582 prioritisation, but not all. Broad-scale prioritisation if applied at regional or biome levels

583 man may facilitate the identification of priority caves. However, we found broad-scale

584 measures underestimated the priorities of highly vulnerable bat caves (i.e., less even

585 distribution of priorities) with a $25 \%$ difference with fine-scale prioritisation (Figure 6, Table

586 5). In addition, fine-scale prioritisation (e.g., national-level priorities) enables community-

587 level interactions and responses to be encompassed and also accounts for rare species

588 and the impacts of threats on local populations (Cajaiba et al., 2021; Tanalgo et al., 2018),

589 highlighting the need for good monitoring and assessment data as a basis for priority

590 setting. Furthermore, context-specific threats (e.g., vulnerability to religious activities in

591 Buddhist regions, where caves often become temples or religious sites) need to be

592 accounted for explicitly for indices to be effective.

593 The integration of vulnerability to effective conservation planning is often

594 challenging due to vague or inconsistent approaches and definition (Sarkar et al., 2006). 
595 While most habitat protection centres on taxonomic diversity (e.g., counts, abundance, 596 and rarity) (Brum et al., 2017; Hartley and Kunin, 2003). Common species can provide

597 ecological services (e.g., nectarivorous cave bats as pollinators, insectivores for pest

598 control) and the reduction of population counts may indicate habitat health due to changes

599 in service provision. Whereas, species are often prioritised based on their combined

600 distinct ecological function, high sensitivity and vulnerability to declines (Mouillot et al.,

601 2013). Within cave ecosystems maintaining the functioning of the subterranean

602 ecosystems requires maintaining both diversity and abundance (Bregović et al., 2019;

603 Phelps et al., 2016; Tanalgo et al., 2018), thus a holistic tool that incorporates diversity,

604 rarity and function is needed as a basis for conservation-decision making. Numerous

605 indices based on different dimensions and attributes of cave biodiversity have been

606 developed but few integrate landscape features, and greater standardisation is needed.

607 Whilst various taxa have been used as indicators for diversity in subterranean habitats

608 (Souza Silva et al., 2015), bats represent holistic surrogates for cave conservation

609 because they not only provide the main source of energy for cave ecosystems but are

610 also easier to assess and reflect changes from both internal and surfaces (Cajaiba et al.,

611 2021; Jones et al., 2009). Our vulnerability index includes not only species diversity

612 measures (Furman and Özgül, 2004; Niu et al., 2007) but also encompasses evolutionary

613 distinctiveness and threat exposure of both species and its habitat (Cajaiba et al., 2021;

614 Phelps et al., 2016; Tanalgo et al., 2018). The inclusion of these measures enables

615 prioritisation of cave habitats with rare and higher functional diversity attributes (Jetz et

616 al., 2014; Srivastava et al., 2012) complimenting the metrics based on geopolitical

617 endemism and conservation status from IUCN (Isaac et al., 2007; Jetz et al., 2014; 
618 Martín-López et al., 2009) which are commonly used within prioritisation schemes. While

619 the expert-based Red list developed by the IUCN is the most comprehensive basis for

620 conservation and species protection, it is not free from biases (Hughes et al., 2021;

621 Martín-López et al., 2011; Trimble and Aarde, 2010), especially for bats, in which a large

622 proportion of species are either taxonomically and spatially under-sampled particularly in

623 most megadiverse and developing countries (Zamora-Gutierrez et al., 2019).

624 For an index to be effective, a clear understanding of diversity patterns and

625 priorities at national levels is an essential first step to implementable policy targets (Doi

626 and Takahara, 2016; Rudd et al., 2011) (Figure 7). Additionally, few countries have any

627 policy related to the protection of caves and their biota (Whitten, 2009). For example, in

628 the Philippines, the National Cave Conservation Committee aims to identify caves for 629 protection has very broad criteria and focused on archaeological and touristic values

630 rather than ecological components which hamper effective protection or priority setting.

631 National Biodiversity Action Plans (NBSAPS) should include standard provisions for

632 priority identification and monitoring which include all habitats (Martín-López et al., 2009),

633 thus frameworks such as this can provide information that is both consistent between

634 countries and can be usefully applied at national levels.

635 Caveats and opportunities for bat cave conservation in the Anthropocene

636 The uneven distribution of threats and a lack of understanding of their impacts

637 remains a challenge for global bat conservation. Developing any index requires

638 pragmatism in finding indicators that are reliable enough, but for which there is sufficient

639 data available. For example, the interpretation of extinction risk requires caution as factors

640 may act in synergy and we could not fully account for the intensity of human-induced 
641 threats (Howard et al., 2019). This assessing vulnerability is particularly challenging to

642 identify in the context of cave biota, in which even a single disturbance may alter the

643 entire sensitive biota and ecosystem, yet causal drivers are challenging, and other

644 proximal indicators (e.g. accessibility) must be used as indicators (Cajaiba et al., 2021;

645 De Oliveira et al., 2018; Phelps et al., 2018). Furthermore, the degree of expertise

646 required for bat and cave studies means less data is available compared to other

647 taxonomic groups (Herkt et al., 2017; Zamora-Gutierrez et al., 2019). For instance, in our

648 cave prioritisation, we only accounted the $59 \%$ of the global cave-dwelling species, and

649 species coverage varied by region, for example, Indonesia has some of the highest

650 estimated bat cave species richness yet its contribution to the dataset based on surveys

651 and assessments is among the lowest. In addition, cave community data is lacking for

652 biodiverse regions such as from the Afrotropical and Indomalayan regions. Furthermore,

653 accurate systematic and taxonomic studies for bats are vital to appropriate conservation

654 as caves host high endemism and many cave bats (e.g., Rhinolophids) have high

655 numbers of as yet undescribed cryptic species (Mayer et al., 2007). The lack of 656 distribution data may be explicitly linked to the lack of funding in most biodiverse countries

657 (McClanahan and Rankin, 2016), hindering effective assessment in countries most in

658 need. Conversely within Europe, the UNEP-EUROBATS and EU habitats directive

659 provides guidance and regulations, which comprehensively include the protection and

660 monitoring of bats and caves in its territory and member states making parallel and

661 equitable policies for large scale protection (European Commission, 2021;

662 UNEP/EUROBATS, 2020). Policies and targets that accurately account for and include

663 monitoring in threatened systems such as caves and karsts are urgently needed and 
664 highlight a need for ecosystem-based conservation targets, as species-specific targets 665 risk missing key habitats for neglected taxa (Hughes et al., 2021).

\section{Synthesis}

667 Finally, to protect and conserve these ecosystems it is crucial that we identify 668 priorities in species and habitat-level, and map vulnerable cave habitats with the highest

669 biodiversity and distinctiveness. We illustrate a comprehensive index to integrate facets

670 of diversity and risk to provide a simple and scalable approach to prioritising caves for

671 protection and delineating between those in need of urgent intervention (high diversity but

672 high threat) and those which whilst not yet threatened require monitoring to ensure they

673 remain protected (Figure 7). Whilst further data is needed, especially for data-poor,

674 species-rich regions, relying on IUCN data alone risks misleading effective priorities (e.g.,

675 spatial mismatches in the Indomalayan region) (Martín-López et al., 2011; Milner-Gulland

676 et al., 2006). The IUCN Red list must be utilised alongside other tools and measures of

677 decision making; thus, we advocate an integrative conservation approach that

678 synthesises various dimensions of conservation. Furthermore, habitat focused indices

679 complement other recent initiatives such as the IUCN Red List of ecosystems, and new

680 IUCN ecosystem typology, but also includes high-resolution data which can be

681 challenging to include in broader scale indices.

682 Cave ecosystems host both high diversity and site-specific endemism, and are

683 used by up to $30 \%$ of all bat species, yet are rarely included in global priorities (Mammola 684 et al., 2019a; Sánchez-Fernández et al., 2021). The persistence of high levels of

685 biodiversity in caves is linked to more pristine cave environments with less anthropogenic 686 pressure. Large spatial coverage (e.g., biome-dependent) analysis decreases the 
687 evenness in priority distribution in comparison to site-level, thus its conservation 688 application to protect caves is scale dependant (e.g., national-level or biome-wide 689 protection), and scalability in indices is also important. Conservation decision making 690 depends on the clear delineation between what is important and urgent to develop 691 priorities, as funding and resources are limited and often focus on a subset of taxa which 692 may not be representative (Gordon et al., 2019; Joseph et al., 2009; Wilson et al., 2007).

693 Ideally, priority-setting should encompass not only the aspects of biological diversity and

694 threats but should also include the country's socio-economic capacity, the implementation 695 cost, and political attributes. Thus, it is imperative to set realistic and cost-effective 696 priorities based on areas with higher risks, vulnerabilities and could protect larger 697 communities (Joseph et al., 2009; Rudd et al., 2011).

698 Our study identifies gaps and priorities for bat cave conservation. We highlight just 699 how many high diversity caves are currently threatened (red caves) and those that are 700 currently at low risk but biotically important (green caves), which reflects what form of 701 intervention may be needed for different sites. To address global gaps for effective 702 conservation and develop more rigorous priorities, collaborative efforts among bat 703 scientists are necessary to enable the development of an effective international agenda 704 and nationally adaptable goals for cave prioritisation and assessment. This framework 705 calls for standardisation of methods of bat cave assessment and monitoring based on key 706 indicators for diversity and threat, and for this data to be more widely shared to facilitate 707 better conservation and policy. Furthermore, maintaining cave bat diversity relies on their 708 inclusion into conservation agendas and priorities, and the use of science-based targets 709 and frameworks, and synthesising conservation effectiveness (e.g., Conservation 
710 Evidence Initiative (Conservation Evidence, 2021)) to ensure that approaches such as

711 that detailed here can be effectively applied to enable key sites to be identified, and

712 appropriately protected on a global basis, even despite a lack of data in many regions.

713 Ultimately, developing effective decisions requires comparable data and standardised

714 frameworks to enable its translation into policy and practice and effectively protect

715 threatened species and facilitate sustainable development.

\section{Data accessibility statement}

717 The data which are used in this study have been provided in the supplementary material

718 accompanied with this manuscript.

719 Declaration of competing interest

720 The authors declare that they have no known competing financial interests or personal

721 relationships that could have appeared to influence the work reported in this paper.

722 CRediT authorship contribution statement

$723 \mathrm{KCT}$ and $\mathrm{ACH}$ contributed equally to the work. $\mathrm{KCT}$ and $\mathrm{ACH}$ conceptualised and

724 designed the study. KCT, HFMO, and $\mathrm{ACH}$ collected the data. KCT and $\mathrm{ACH}$ analysed

725 the data. KCT and $\mathrm{ACH}$ led the manuscript writing. KCT performed data visualisation.

$726 \mathrm{ACH}$ supervised the project. All authors contributed to the editing, reviewing, and

727 approved the final version of the manuscript.

\section{Acknowledgements}

729 This research project is part of the Global Bat Cave Vulnerability and Conservation

730 Mapping Initiative project with support from the Chinese National Natural Science

731 Foundation (ACH) (Grant No. U1602265, Mapping Karst Biodiversity in Yunnan), the 
732 Strategic Priority Research Program of the Chinese Academy of Sciences (ACH) (Grant

733 No. XDA20050202), the Chinese Academy of Sciences Southeast Asia Biodiversity

734 Research Center fund $(\mathrm{ACH})(\mathrm{Grant}$ No. Y4ZK111B01). This work is part of the Doctoral

735 project of KCT supported by the University of Chinese Academy of Sciences and Chinese

736 Government Scholarship council, P.R. China (CGS No. 2018SLJ023249) and the

737 Zukunftskolleg Connect Fellowship at the University of Konstanz.

738 We also would like to acknowledge the DarkCiDeS consortium

739 (https://darkcides.org/our-team/) for their invaluable contribution of cave data provided in

740 the separate paper which will hopefully provide a key resource to derived studies such as

741 this. We would also like to thank the logistics and field team in XTBG (Ding Zinan, Chen

742 Yanhua, Chen Xing) for support in the elements of the work, and Fu Wuxiang for

743 compiling the data for Chinese caves. We would also like to thank reviewers and editors

744 for their constructive remarks which have improved the paper.

745

746

747

748

749

750

751

752

753

754

755

756

757

758

759

760

761

762

763

764

\section{References}

Amori, G., Chiozza, F., Rondinini, C., Luiselli, L., 2011. Country-based patterns of total species richness, endemicity, and threatened species richness in African rodents and insectivores. Biodivers. Conserv. 20, 1225-1237. https://doi.org/10.1007/s10531-011-0024-1

Arponen, A., 2012. Prioritizing species for conservation planning. Biodivers. Conserv. 21, 875-893. https://doi.org/10.1007/s10531-012-0242-1

Atwood, T.B., Valentine, S.A., Hammill, E., McCauley, D.J., Madin, E.M.P., Beard, K.H., Pearse, W.D., 2020. Herbivores at the highest risk of extinction among mammals, birds, and reptiles. Sci. Adv. 6, eabb8458. https://doi.org/10.1126/sciadv.abb8458

Aziz, S.A., McConkey, K., Tanalgo, K., Sritongchuay, T., Low, M.-R., Yong, J.Y., Mildenstein, T.L., Nuevo-Diego, C.E., Lim, V.-C., Racey, P.A., 2021. The critical importance of Old World fruit bats for healthy ecosystems and economies. Front. Ecol. Evol. 9. https://doi.org/10.3389/fevo.2021.641411

Barclay, R.M.R., Ulmer, J., MacKenzie, C.J.A., Thompson, M.S., Olson, L., McCool, J., Cropley, E., Poll, G., 2004. Variation in the reproductive rate of bats. Can. J. Zool. 82, 688-693. https://doi.org/10.1139/z04-057 
765

766

767

768

769

770

771

772

773

774

775

776

777

778

779

780

781

782

783

784

785

786

787

788

789

790

791

792

793

794

795

796

797

798

799

800

801

802

803

804

805

806

807

808

809

Bland, L.M., Collen, B., Orme, C.D.L., Bielby, J., 2015. Predicting the conservation status of data-deficient species. Conserv. Biol. 29, 250-259. https://doi.org/10.1111/cobi.12372

Bregović, P., Fišer, C., Zagmajster, M., 2019. Contribution of rare and common species to subterranean species richness patterns. Ecol. Evol. 9, 11606-11618. https://doi.org/10.1002/ece3.5604

Brum, F.T., Graham, C.H., Costa, G.C., Hedges, S.B., Penone, C., Radeloff, V.C., Rondinini, C., Loyola, R., Davidson, A.D., 2017. Global priorities for conservation across multiple dimensions of mammalian diversity. Proc. Natl. Acad. Sci. 114, 7641-7646. https://doi.org/10.1073/pnas.1706461114

Burgin, C.J., Colella, J.P., Kahn, P.L., Upham, N.S., 2018. How many species of mammals are there? J. Mammal. 99, 1-14. https://doi.org/10.1093/jmammal/gyx147

Cajaiba, R.L., Périco, E., da Silva, W.B., Vieira, T.B., dos Santos, F.M.B., Santos, M., 2021. Are neotropical cave-bats good landscape integrity indicators? Some clues when exploring the cross-scale interactions between underground and aboveground ecosystems. Ecol. Indic. 122, 107258. https://doi.org/10.1016/j.ecolind.2020.107258

Cardiff, S.G., Ratrimomanarivo, F.H., Rembert, G., Goodman, S.M., 2009. Hunting, disturbance and roost persistence of bats in caves at Ankarana, northern Madagascar. Afr. J. Ecol. 47, 640-649. https://doi.org/10.1111/j.13652028.2008.01015.x

Cardinale, B.J., Duffy, J.E., Gonzalez, A., Hooper, D.U., Perrings, C., Venail, P., Narwani, A., Mace, G.M., Tilman, D., Wardle, D.A., Kinzig, A.P., Daily, G.C., Loreau, M., Grace, J.B., Larigauderie, A., Srivastava, D.S., Naeem, S., 2012. Biodiversity loss and its impact on humanity. Nature 486, 59-67. https://doi.org/10.1038/nature11148

Ceballos, G., Ehrlich, P.R., 2002. Mammal Population Losses and the Extinction Crisis. Science 296, 904-907. https://doi.org/10.1126/science.1069349

Ceballos, G., Ehrlich, P.R., Barnosky, A.D., García, A., Pringle, R.M., Palmer, T.M., 2015. Accelerated modern human-induced species losses: Entering the sixth mass extinction. Sci. Adv. 1, e1400253. https://doi.org/10.1126/sciadv.1400253

Chandra, A., Idrisova, A., 2011. Convention on Biological Diversity: a review of national challenges and opportunities for implementation. Biodivers. Conserv. 20, 32953316. https://doi.org/10.1007/s10531-011-0141-x

Clark, J.A., May, R.M., 2002. Taxonomic Bias in Conservation Research. Science 297, 191-192. https://doi.org/10.1126/science.297.5579.191b

Clements, R., Sodhi, N.S., Schilthuizen, M., Ng, P.K.L., 2006. Limestone Karsts of Southeast Asia: Imperiled Arks of Biodiversity. BioScience 56, 733-742. https://doi.org/10.1641/0006-3568(2006)56[733:LKOSAl]2.0.CO;2

Conenna, I., Rocha, R., Russo, D., Cabeza, M., 2017. Insular bats and research effort: a review of global patterns and priorities. Mammal Rev. 47, 169-182. https://doi.org/10.1111/mam.12090

Conservaton Evidence, 2021. Conservation Evidence: Evidence Data [WWW Document]. URL 
810

811

812

813

814

815

816

817

818

819

820

821

822

823

824

825

826

827

828

829

830

831

832

833

834

835

836

837

838

839

840

841

842

843

844

845

846

847

848

849

850

851

852

853

https://www.conservationevidence.com/data/index/?synopsis_id[]=14 (accessed 3.23.21).

Crisp, M.D., Laffan, S., Linder, H.P., Monro, A., 2001. Endemism in the Australian flora. J. Biogeogr. 28, 183-198. https://doi.org/10.1046/j.1365-2699.2001.00524.x

Crowther, T., Glick, H., Covey, K., 2015. Global tree density map [WWW Document]. URL https://elischolar.library.yale.edu/yale_fes_data/1/ (accessed 3.23.21).

Cunha, A.O.B., Bezerra, J.D.P., Oliveira, T.G.L., Barbier, E., Bernard, E., Machado, A.R., Souza-Motta, C.M., 2020. Living in the dark: Bat caves as hotspots of fungal diversity. PLOS ONE 15, e0243494. https://doi.org/10.1371/journal.pone.0243494

Day, M., Urich, P., 2000. An assessment of protected karst landscapes in Southeast Asia [WWW Document]. Cave Karst Sci. URL https://eurekamag.com/research/030/010/030010724.php (accessed 7.5.19).

De Oliveira, H.F.M., Oprea, M., Dias, R.I., 2018. Distributional Patterns and Ecological Determinants of Bat Occurrence Inside Caves: A Broad Scale Meta-Analysis. Diversity 10, 49. https://doi.org/10.3390/d10030049

Deharveng, L., Bedos, A., 2018. Diversity of Terrestrial Invertebrates in Subterranean Habitats, in: Moldovan, O.T., Kováč, L'., Halse, S. (Eds.), Cave Ecology, Ecological Studies. Springer International Publishing, Cham, pp. 107-172. https://doi.org/10.1007/978-3-319-98852-8_7

Doi, H., Takahara, T., 2016. Global patterns of conservation research importance in different countries of the world. PeerJ 4, e2173. https://doi.org/10.7717/peerj.2173

Dolman, P.M., Panter, C.J., Mossman, H.L., 2012. The biodiversity audit approach challenges regional priorities and identifies a mismatch in conservation. J. Appl. Ecol. 49, 986-997. https://doi.org/10.1111/j.1365-2664.2012.02174.x

Earth at Night (Black Marble) 2016 Color Maps [WWW Document], 2019. URL https://www.visibleearth.nasa.gov/images/144898/earth-at-night-black-marble2016-color-maps (accessed 3.23.21).

Ellis, E.C., Kaplan, J.O., Fuller, D.Q., Vavrus, S., Goldewijk, K.K., Verburg, P.H., 2013. Used planet: A global history. Proc. Natl. Acad. Sci. 110, 7978-7985. https://doi.org/10.1073/pnas.1217241110

Etard, A., Morrill, S., Newbold, T., 2020. Global gaps in trait data for terrestrial vertebrates. Glob. Ecol. Biogeogr. n/a. https://doi.org/10.1111/geb.13184

European Commission, 2021. The Habitats Directive - Environment - European Commission [WWW Document]. URL https://ec.europa.eu/environment/nature/legislation/habitatsdirective/index_en.ht $\mathrm{m}$ (accessed 8.5.21).

Faurby, S., Davis, M., Pedersen, R.Ø., Schowanek, S.D., Antonelli1, A., Svenning, J.C., 2018. PHYLACINE 1.2: The Phylogenetic Atlas of Mammal Macroecology. Ecology 99, 2626-2626. https://doi.org/10.1002/ecy.2443

Ferreira, R.L., 2019. Chapter 57 - Guano communities, in: White, W.B., Culver, D.C., Pipan, T. (Eds.), Encyclopedia of Caves (Third Edition). Academic Press, pp. 474-484. https://doi.org/10.1016/B978-0-12-814124-3.00057-1 
854

855

856

857

858

859

860

861

862

863

864

865

866

867

868

869

870

871

872

873

874

875

876

877

878

879

880

881

882

883

884

885

886

887

888

889

890

891

892

893

894

895

896

897

898
Fleming, P.A., Bateman, P.W., 2016. The good, the bad, and the ugly: which Australian terrestrial mammal species attract most research? Mammal Rev. 46, 241-254. https://doi.org/10.1111/mam.12066

Ford, A.T., Cooke, S.J., Goheen, J.R., Young, T.P., 2017. Conserving Megafauna or Sacrificing Biodiversity? BioScience 67, 193-196. https://doi.org/10.1093/biosci/biw163

Francis, C.M., Borisenko, A.V., Ivanova, N.V., Eger, J.L., Lim, B.K., Guillén-Servent, A., Kruskop, S.V., Mackie, I., Hebert, P.D.N., 2010. The Role of DNA Barcodes in Understanding and Conservation of Mammal Diversity in Southeast Asia. PLOS ONE 5, e12575. https://doi.org/10.1371/journal.pone.0012575

Frick, W.F., Kingston, T., Flanders, J., 2019. A review of the major threats and challenges to global bat conservation. Ann. N. Y. Acad. Sci. 0. https://doi.org/10.1111/nyas.14045

Furey, N.M., Racey, P.A., 2016. Conservation Ecology of Cave Bats, in: Voigt, C.C., Kingston, T. (Eds.), Bats in the Anthropocene: Conservation of Bats in a Changing World. Springer International Publishing, Cham, pp. 463-500. https://doi.org/10.1007/978-3-319-25220-9_15

Furman, A., Özgül, A., 2004. The distribution of cave-dwelling bats and conservation status of underground habitats in Northwestern Turkey. Biol. Conserv. 120, 243248. https://doi.org/10.1016/j.biocon.2004.02.019

Gallucci, M., 2019. GAMLj: General analyses for linear models.[jamovi module]. Version.

Goodman, S.M., 2006. Hunting of Microchiroptera in south-western Madagascar. Oryx 40, 225-228. https://doi.org/10.1017/S0030605306000354

Gordon, E.R., Butt, N., Rosner-Katz, H., Binley, A.D., Bennett, J.R., 2019. Relative costs of conserving threatened species across taxonomic groups. Conserv. Biol. 0. https://doi.org/10.1111/cobi.13382

Groves, C.R., Jensen, D.B., Valutis, L.L., Redford, K.H., Shaffer, M.L., Scott, J.M., Baumgartner, J.V., Higgins, J.V., Beck, M.W., Anderson, M.G., 2002. Planning for Biodiversity Conservation: Putting Conservation Science into Practice. BioScience 52, 499. https://doi.org/10.1641/00063568(2002)052[0499:PFBCPC]2.0.CO;2

Halpern, B.S., Pyke, C.R., Fox, H.E., Haney, J.C., Schlaepfer, M.A., Zaradic, P., 2006. Gaps and Mismatches between Global Conservation Priorities and Spending. Conserv. Biol. 20, 56-64. https://doi.org/10.1111/j.1523-1739.2005.00258.x

Hammer, Ø., Harper, D., Ryan, P., 2001. PAST : Paleontological Statistics Software Package for Education and Data Analysis. Palaeontol. Electron. 4.

Hartley, S., Kunin, W.E., 2003. Scale Dependency of Rarity, Extinction Risk, and Conservation Priority. Conserv. Biol. 17, 1559-1570. https://doi.org/10.1111/j.1523-1739.2003.00015.x

Herkt, K.M.B., Skidmore, A.K., Fahr, J., 2017. Macroecological conclusions based on IUCN expert maps: A call for caution. Glob. Ecol. Biogeogr. 26, 930-941. https://doi.org/10.1111/geb.12601

Hernández-Quiroz, N.S., Badano, E.I., Barragán-Torres, F., Flores, J., Pinedo-Álvarez, C., 2018. Habitat suitability models to make conservation decisions based on 
areas of high species richness and endemism. Biodivers. Conserv. 27, 31853200. https://doi.org/10.1007/s10531-018-1596-9

902

903

904

905

906

907

908

909

910

911

912

913

914

915

916

917

918

919

920

921

922

923

924

925

926

927

928

929

930

931

932

933

934

935

936

937

938

939

940

941

942

943

944

Hoffmann, M., Hilton-Taylor, C., Angulo, A., Böhm, M., Brooks, T.M., Butchart, S.H.M., Carpenter, K.E., Chanson, J., Collen, B., Cox, N.A., Darwall, W.R.T., Dulvy, N.K., Harrison, L.R., Katariya, V., Pollock, C.M., Quader, S., Richman, N.I., Rodrigues, A.S.L., Tognelli, M.F., Vié, J.-C., Aguiar, J.M., Allen, D.J., Allen, G.R., Amori, G., Ananjeva, N.B., Andreone, F., Andrew, P., Ortiz, A.L.A., Baillie, J.E.M., Baldi, R., Bell, B.D., Biju, S.D., Bird, J.P., Black-Decima, P., Blanc, J.J., Bolaños, F., Bolivar-G, W., Burfield, I.J., Burton, J.A., Capper, D.R., Castro, F., Catullo, G., Cavanagh, R.D., Channing, A., Chao, N.L., Chenery, A.M., Chiozza, F., Clausnitzer, V., Collar, N.J., Collett, L.C., Collette, B.B., Fernandez, C.F.C., Craig, M.T., Crosby, M.J., Cumberlidge, N., Cuttelod, A., Derocher, A.E., Diesmos, A.C., Donaldson, J.S., Duckworth, J.W., Dutson, G., Dutta, S.K., Emslie, R.H., Farjon, A., Fowler, S., Freyhof, J., Garshelis, D.L., Gerlach, J., Gower, D.J., Grant, T.D., Hammerson, G.A., Harris, R.B., Heaney, L.R., Hedges, S.B., Hero, J.-M., Hughes, B., Hussain, S.A., M, J.I., Inger, R.F., Ishii, N., Iskandar, D.T., Jenkins, R.K.B., Kaneko, Y., Kottelat, M., Kovacs, K.M., Kuzmin, S.L., Marca, E.L., Lamoreux, J.F., Lau, M.W.N., Lavilla, E.O., Leus, K., Lewison, R.L., Lichtenstein, G., Livingstone, S.R., Lukoschek, V., Mallon, D.P., McGowan, P.J.K., Mclvor, A., Moehlman, P.D., Molur, S., Alonso, A.M., Musick, J.A., Nowell, K., Nussbaum, R.A., Olech, W., Orlov, N.L., Papenfuss, T.J., Parra-Olea, G., Perrin, W.F., Polidoro, B.A., Pourkazemi, M., Racey, P.A., Ragle, J.S., Ram, M., Rathbun, G., Reynolds, R.P., Rhodin, A.G.J., Richards, S.J., Rodríguez, L.O., Ron, S.R., Rondinini, C., Rylands, A.B., Mitcheson, Y.S. de, Sanciangco, J.C., Sanders, K.L., Santos-Barrera, G., Schipper, J., Self-Sullivan, C., Shi, Y., Shoemaker, A., Short, F.T., Sillero-Zubiri, C., Silvano, D.L., Smith, K.G., Smith, A.T., Snoeks, J., Stattersfield, A.J., Symes, A.J., Taber, A.B., Talukdar, B.K., Temple, H.J., Timmins, R., Tobias, J.A., Tsytsulina, K., Tweddle, D., Ubeda, C., Valenti, S.V., Dijk, P.P. van, Veiga, L.M., Veloso, A., Wege, D.C., Wilkinson, M., Williamson, E.A., Xie, F., Young, B.E., Akçakaya, H.R., Bennun, L., Blackburn, T.M., Boitani, L., Dublin, H.T., Fonseca, G.A.B. da, Gascon, C., Lacher, T.E., Mace, G.M., Mainka, S.A., McNeely, J.A., Mittermeier, R.A., Reid, G.M., Rodriguez, J.P., Rosenberg, A.A., Samways, M.J., Smart, J., Stein, B.A., Stuart, S.N., 2010. The Impact of Conservation on the Status of the World's Vertebrates. Science 330, 1503-1509. https://doi.org/10.1126/science.1194442

Howard, C., Flather, C.H., Stephens, P.A., 2019. What drives at-risk species richness? Environmental factors are more influential than anthropogenic factors or biological traits. Conserv. Lett. 12, e12624. https://doi.org/10.1111/conl.12624

Hughes, A., Orr, M., Yang, Q., Qiao, H., 2020. Effectively and accurately mapping global biodiversity patterns for different regions and taxa. Glob. Ecol. Biogeogr. https://doi.org/10.22541/au.159654424.40253314

Hughes, A.C., 2019. Understanding and minimizing environmental impacts of the Belt and Road Initiative. Conserv. Biol. 33, 883-894. https://doi.org/10.1111/cobi.13317

Hughes, A.C., 2017. Mapping priorities for conservation in Southeast Asia. Biol. Conserv. 209, 395-405. https://doi.org/10.1016/j.biocon.2017.03.007 
945

946

947

948

949

950

951

952

953

954

955

956

957

958

959

960

961

962

963

964

965

966

967

968

969

970

971

972

973

974

975

976

977

978

979

980

981

982

983

984

985

986

987

988

989
Hughes, Alice C., 2017. Understanding the drivers of Southeast Asian biodiversity loss. Ecosphere 8, e01624. https://doi.org/10.1002/ecs2.1624

Hughes, A.C., Qiao, H., Orr, M.C., 2021. Extinction Targets Are Not SMART (Specific, Measurable, Ambitious, Realistic, and Time Bound). BioScience 71, 115-118. https://doi.org/10.1093/biosci/biaa148

Index Mundi, 2020. Hydraulic Cement Production by Country (Thousand metric tons) [WWW Document]. URL https://www.indexmundi.com/minerals/?product=cement\&graph=production (accessed 10.16.20).

Isaac, N.J.B., Turvey, S.T., Collen, B., Waterman, C., Baillie, J.E.M., 2007. Mammals on the EDGE: Conservation Priorities Based on Threat and Phylogeny. PLOS ONE 2, e296. https://doi.org/10.1371/journal.pone.0000296

Jetz, W., McGeoch, M.A., Guralnick, R., Ferrier, S., Beck, J., Costello, M.J., Fernandez, M., Geller, G.N., Keil, P., Merow, C., Meyer, C., Muller-Karger, F.E., Pereira, H.M., Regan, E.C., Schmeller, D.S., Turak, E., 2019. Essential biodiversity variables for mapping and monitoring species populations. Nat. Ecol. Evol. 3, 539-551. https://doi.org/10.1038/s41559-019-0826-1

Jetz, W., Thomas, G.H., Joy, J.B., Redding, D.W., Hartmann, K., Mooers, A.O., 2014. Global Distribution and Conservation of Evolutionary Distinctness in Birds. Curr. Biol. 24, 919-930. https://doi.org/10.1016/j.cub.2014.03.011

Jones, G., Jacobs, D.S., Kunz, T.H., Willig, M.R., Racey, P.A., 2009. Carpe noctem: the importance of bats as bioindicators. Endanger. Species Res. 8, 93-115. https://doi.org/10.3354/esr00182

Jones, K.E., Purvis, A., Gittleman, J.L., 2003. Biological Correlates of Extinction Risk in Bats. Am. Nat. 161, 601-614. https://doi.org/10.1086/368289

Joseph, L.N., Maloney, R.F., Possingham, H.P., 2009. Optimal Allocation of Resources among Threatened Species: a Project Prioritization Protocol. Conserv. Biol. 23, 328-338. https://doi.org/10.1111/j.1523-1739.2008.01124.x

Keith, D.A., Rodríguez, J.P., Brooks, T.M., Burgman, M.A., Barrow, E.G., Bland, L., Comer, P.J., Franklin, J., Link, J., McCarthy, M.A., Miller, R.M., Murray, N.J., Nel, J., Nicholson, E., Oliveira-Miranda, M.A., Regan, T.J., Rodríguez-Clark, K.M., Rouget, M., Spalding, M.D., 2015. The IUCN Red List of Ecosystems: Motivations, Challenges, and Applications. Conserv. Lett. 8, 214-226. https://doi.org/10.1111/conl.12167

Labay, K., Burger, M.H., Bellora, J.D., Schulz, K.J., DeYoung, J.H., Seal, R.R., Bradley, D.C., Mauk, J.L., San Juan, C.A., 2017. Global Distribution of Selected Mines, Deposits, and Districts of Critical Minerals. https://doi.org/10.5066/F7GH9GQR

Laffan, S.W., Crisp, M.D., 2003. Assessing endemism at multiple spatial scales, with an example from the Australian vascular flora. J. Biogeogr. 30, 511-520. https://doi.org/10.1046/j.1365-2699.2003.00875.x

Lewandowski, A.S., Noss, R.F., Parsons, D.R., 2010. The Effectiveness of Surrogate Taxa for the Representation of Biodiversity. Conserv. Biol. 24, 1367-1377. https://doi.org/10.1111/j.1523-1739.2010.01513.x

Liew, T.-S., Price, L., Clements, G.R., 2016. Using Google Earth to Improve the Management of Threatened Limestone Karst Ecosystems in Peninsular 
990

991

992

993

994

995

996

997

998

999

1000

1001

1002

1003

1004

1005

1006

1007

1008

1009

1010

1011

1012

1013

1014

1015

1016

1017

1018

1019

1020

1021

1022

1023

1024

1025

1026

1027

1028

1029

1030

1031

1032

1033

1034

Malaysia. Trop. Conserv. Sci. 9, 903-920.

https://doi.org/10.1177/194008291600900219

Maggi, F., Tang, F.H.M., Cecilia, D. la, McBratney, A., 2019. PEST-CHEMGRIDS, global gridded maps of the top 20 crop-specific pesticide application rates from 2015 to 2025. Sci. Data 6, 1-20. https://doi.org/10.1038/s41597-019-0169-4

Mammola, S., Cardoso, P., Culver, D.C., Deharveng, L., Ferreira, R.L., Fišer, C., Galassi, D.M.P., Griebler, C., Halse, S., Humphreys, W.F., Isaia, M., Malard, F., Martinez, A., Moldovan, O.T., Niemiller, M.L., Pavlek, M., Reboleira, A.S.P.S., Souza-Silva, M., Teeling, E.C., Wynne, J.J., Zagmajster, M., 2019a. Scientists' Warning on the Conservation of Subterranean Ecosystems. BioScience. https://doi.org/10.1093/biosci/biz064

Mammola, S., Cardoso, P., Culver, D.C., Deharveng, L., Ferreira, R.L., Fišer, C., Galassi, D.M.P., Griebler, C., Halse, S., Humphreys, W.F., Isaia, M., Malard, F., Martinez, A., Moldovan, O.T., Niemiller, M.L., Pavlek, M., Reboleira, A.S.P.S., Souza-Silva, M., Teeling, E.C., Wynne, J.J., Zagmajster, M., 2019b. Scientists' Warning on the Conservation of Subterranean Ecosystems. BioScience 69, 641650. https://doi.org/10.1093/biosci/biz064

Margules, C.R., Pressey, R.L., Williams, P.H., 2002. Representing biodiversity: Data and procedures for identifying priority areas for conservation. J. Biosci. 27, 309326. https://doi.org/10.1007/BF02704962

Martín-López, B., González, J.A., Montes, C., 2011. The pitfall-trap of species conservation priority setting. Biodivers. Conserv. 20, 663-682. https://doi.org/10.1007/s10531-010-9973-z

Martín-López, B., Montes, C., Ramírez, L., Benayas, J., 2009. What drives policy decision-making related to species conservation? Biol. Conserv. 142, 13701380. https://doi.org/10.1016/j.biocon.2009.01.030

Mayer, F., Dietz, C., Kiefer, A., 2007. Molecular species identification boosts bat diversity. Front. Zool. 4, 4. https://doi.org/10.1186/1742-9994-4-4

McClanahan, T.R., Rankin, P.S., 2016. Geography of conservation spending, biodiversity, and culture. Conserv. Biol. 30, 1089-1101. https://doi.org/10.1111/cobi.12720

McClure, M.L., Crowley, D., Haase, C.G., McGuire, L.P., Fuller, N.W., Hayman, D.T.S., Lausen, C.L., Plowright, R.K., Dickson, B.G., Olson, S.H., 2020. Linking surface and subterranean climate: implications for the study of hibernating bats and other cave dwellers. Ecosphere 11, e03274. https://doi.org/10.1002/ecs2.3274

McGeoch, M.A., Butchart, S.H.M., Spear, D., Marais, E., Kleynhans, E.J., Symes, A., Chanson, J., Hoffmann, M., 2010. Global indicators of biological invasion: species numbers, biodiversity impact and policy responses. Divers. Distrib. 16, 95-108. https://doi.org/10.1111/j.1472-4642.2009.00633.x

Medellin, R.A., Wiederholt, R., Lopez-Hoffman, L., 2017. Conservation relevance of bat caves for biodiversity and ecosystem services. Biol. Conserv., Small Natural Features 211, 45-50. https://doi.org/10.1016/j.biocon.2017.01.012

Meijer, J.R., Huijbregts, M.A.J., Schotten, K.C.G.J., Schipper, A.M., 2018. Global patterns of current and future road infrastructure. Environ. Res. Lett. 13, 064006. https://doi.org/10.1088/1748-9326/aabd42 
1035

1036

1037

1038

1039

1040

1041

1042

1043

1044

1045

1046

1047

1048

1049

1050

1051

1052

1053

1054

1055

1056

1057

1058

1059

1060

1061

1062

1063

1064

1065

1066

1067

1068

1069

1070

1071

1072

1073

1074

1075

1076

1077

1078

1079

1080

Mickleburgh, S., Waylen, K., Racey, P., 2009. Bats as bushmeat: a global review. Oryx 43, 217-234. https://doi.org/10.1017/S0030605308000938

Mildenstein, T., Tanshi, I., Racey, P.A., 2016. Exploitation of Bats for Bushmeat and Medicine, in: Voigt, C.C., Kingston, T. (Eds.), Bats in the Anthropocene: Conservation of Bats in a Changing World. Springer International Publishing, Cham, pp. 325-375. https://doi.org/10.1007/978-3-319-25220-9_12

Milner-Gulland, E.J., Kreuzberg-Mukhina, E., Grebot, B., Ling, S., Bykova, E., Abdusalamov, I., Bekenov, A., Gärdenfors, U., Hilton-Taylor, C., Salnikov, V., Stogova, L., 2006. Application of IUCN Red Listing Criteria at the Regional and National Levels: A Case Study from Central Asia. Biodivers. Conserv. 15, 18731886. https://doi.org/10.1007/s10531-005-4304-5

Monro, A.K., Bystriakova, N., Fu, L., Wen, F., Wei, Y., 2018a. Discovery of a diverse cave flora in China. PLOS ONE 13, e0190801. https://doi.org/10.1371/journal.pone.0190801

Monro, A.K., Bystriakova, N., Fu, L., Wen, F., Wei, Y., 2018b. Discovery of a diverse cave flora in China. PLOS ONE 13, e0190801. https://doi.org/10.1371/journal.pone.0190801

Mouillot, D., Bellwood, D.R., Baraloto, C., Chave, J., Galzin, R., Harmelin-Vivien, M., Kulbicki, M., Lavergne, S., Lavorel, S., Mouquet, N., Paine, C.E.T., Renaud, J., Thuiller, W., 2013. Rare Species Support Vulnerable Functions in High-Diversity Ecosystems. PLOS Biol. 11, e1001569. https://doi.org/10.1371/journal.pbio.1001569

Murray, S.W., Campbell, P., Kingston, T., Zubaid, A., Francis, C.M., Kunz, T.H., 2012. Molecular phylogeny of hipposiderid bats from Southeast Asia and evidence of cryptic diversity. Mol. Phylogenet. Evol. 62, 597-611. https://doi.org/10.1016/j.ympev.2011.10.021

Niu, H., Wang, N., Zhao, L., Liu, J., 2007. Distribution and underground habitats of cave-dwelling bats in China. Anim. Conserv. 10, 470-477. https://doi.org/10.1111/j.1469-1795.2007.00136.x

Olson, D.M., Dinerstein, E., 1998. The Global 200: A Representation Approach to Conserving the Earth's Most Biologically Valuable Ecoregions. Conserv. Biol. 12, 502-515. https://doi.org/10.1046/j.1523-1739.1998.012003502.x

Olson, D.M., Dinerstein, E., Wikramanayake, E.D., Burgess, N.D., Powell, G.V.N., Underwood, E.C., D'amico, J.A., Itoua, I., Strand, H.E., Morrison, J.C., Loucks, C.J., Allnutt, T.F., Ricketts, T.H., Kura, Y., Lamoreux, J.F., Wettengel, W.W., Hedao, P., Kassem, K.R., 2001. Terrestrial Ecoregions of the World: A New Map of Life on EarthA new global map of terrestrial ecoregions provides an innovative tool for conserving biodiversity. BioScience 51, 933-938. https://doi.org/10.1641/0006-3568(2001)051[0933:TEOTWA]2.0.CO;2

Pacifici, M., Santini, L., Marco, M.D., Baisero, D., Francucci, L., Marasini, G.G., Visconti, P., Rondinini, C., 2013. Generation length for mammals. Nat. Conserv. 5, 89-94. https://doi.org/10.3897/natureconservation.5.5734

Phelps, K., Jose, R., Labonite, M., Kingston, T., 2018. Assemblage and Species Threshold Responses to Environmental and Disturbance Gradients Shape Bat Diversity in Disturbed Cave Landscapes. Diversity 10, 55. https://doi.org/10.3390/d10030055 
1081

1082

1083

1084

1085

1086

1087

1088

1089

1090

1091

1092

1093

1094

1095

1096

1097

1098

1099

1100

1101

1102

1103

1104

1105

1106

1107

1108

1109

1110

1111

1112

1113

1114

1115

1116

1117

1118

1119

1120

1121

1122

1123

1124

1125

1126

Phelps, K., Jose, R., Labonite, M., Kingston, T., 2016. Correlates of cave-roosting bat diversity as an effective tool to identify priority caves. Biol. Conserv. 201, 201209. https://doi.org/10.1016/j.biocon.2016.06.023

Pimm, S.L., Jenkins, C.N., Abell, R., Brooks, T.M., Gittleman, J.L., Joppa, L.N., Raven, P.H., Roberts, C.M., Sexton, J.O., 2014. The biodiversity of species and their rates of extinction, distribution, and protection. Science 344, 1246752-1246752. https://doi.org/10.1126/science.1246752

Richman, N.I., Böhm, M., Adams, S.B., Alvarez, F., Bergey, E.A., Bunn, J.J.S., Burnham, Q., Cordeiro, J., Coughran, J., Crandall, K.A., Dawkins, K.L., DiStefano, R.J., Doran, N.E., Edsman, L., Eversole, A.G., Füreder, L., Furse, J.M., Gherardi, F., Hamr, P., Holdich, D.M., Horwitz, P., Johnston, K., Jones, C.M., Jones, J.P.G., Jones, R.L., Jones, T.G., Kawai, T., Lawler, S., LópezMejía, M., Miller, R.M., Pedraza-Lara, C., Reynolds, J.D., Richardson, A.M.M., Schultz, M.B., Schuster, G.A., Sibley, P.J., Souty-Grosset, C., Taylor, C.A., Thoma, R.F., Walls, J., Walsh, T.S., Collen, B., 2015. Multiple drivers of decline in the global status of freshwater crayfish (Decapoda: Astacidea). Philos. Trans. R. Soc. B Biol. Sci. 370, 20140060. https://doi.org/10.1098/rstb.2014.0060

Ripple, W.J., Wolf, C., Newsome, T.M., Galetti, M., Alamgir, M., Crist, E., Mahmoud, M.I., Laurance, W.F., 2017. World Scientists' Warning to Humanity: A Second Notice. BioScience 67, 1026-1028. https://doi.org/10.1093/biosci/bix125

Rose, R.A., Byler, D., Eastman, J.R., Fleishman, E., Geller, G., Goetz, S., Guild, L., Hamilton, H., Hansen, M., Headley, R., Hewson, J., Horning, N., Kaplin, B.A., Laporte, N., Leidner, A., Leimgruber, P., Morisette, J., Musinsky, J., Pintea, L., Prados, A., Radeloff, V.C., Rowen, M., Saatchi, S., Schill, S., Tabor, K., Turner, W., Vodacek, A., Vogelmann, J., Wegmann, M., Wilkie, D., Wilson, C., 2015. Ten ways remote sensing can contribute to conservation. Conserv. Biol. 29, 350-359. https://doi.org/10.1111/cobi.12397

Rudd, M.A., Beazley, K.F., Cooke, S.J., Fleishman, E., Lane, D.E., Mascia, M.B., Roth, R., Tabor, G., Bakker, J.A., Bellefontaine, T., Berteaux, D., Cantin, B., Chaulk, K.G., Cunningham, K., Dobell, R., Fast, E., Ferrara, N., Findlay, C.S., Hallstrom, L.K., Hammond, T., Hermanutz, L., Hutchings, J.A., Lindsay, K.E., Marta, T.J., Nguyen, V.M., Northey, G., Prior, K., Ramirez-Sanchez, S., Rice, J., Sleep, D.J.H., Szabo, N.D., Trottier, G., Toussaint, J.-P., Veilleux, J.-P., 2011. Generation of Priority Research Questions to Inform Conservation Policy and Management at a National Level. Conserv. Biol. 25, 476-484. https://doi.org/10.1111/j.1523-1739.2010.01625.x

Sagot, M., Chaverri, G., 2015. Effects of roost specialization on extinction risk in bats. Conserv. Biol. 29, 1666-1673. https://doi.org/10.1111/cobi.12546

Salafsky, N., Salzer, D., Stattersfield, A.J., Hilton-Taylor, C., Neugarten, R., Butchart, S.H.M., Collen, B., Cox, N., Master, L.L., O'connor, S., Wilkie, D., 2008. A Standard Lexicon for Biodiversity Conservation: Unified Classifications of Threats and Actions. Conserv. Biol. 22, 897-911. https://doi.org/10.1111/j.15231739.2008.00937.x

Sánchez-Fernández, D., Galassi, D.M.P., Wynne, J.J., Cardoso, P., Mammola, S., 2021. Don't forget subterranean ecosystems in climate change agendas. Nat. Clim. Change 11, 458-459. https://doi.org/10.1038/s41558-021-01057-y 
1127

1128

1129

1130

1131

1132

1133

1134

1135

1136

1137

1138

1139

1140

1141

1142

1143

1144

1145

1146

1147

1148

1149

1150

1151

1152

1153

1154

1155

1156

1157

1158

1159

1160

1161

1162

1163

1164

1165

1166

1167

1168

1169

1170

1171

1172

Sarkar, S., Pressey, R.L., Faith, D.P., Margules, C.R., Fuller, T., Stoms, D.M., Moffett, A., Wilson, K.A., Williams, K.J., Williams, P.H., Andelman, S., 2006. Biodiversity Conservation Planning Tools: Present Status and Challenges for the Future. Annu. Rev. Environ. Resour. 31, 123-159. https://doi.org/10.1146/annurev.energy.31.042606.085844

SEDAC, 2020. Population Density, v4: Gridded Population of the World (GPW), v4 | SEDAC.

Sedlock, J.L., Jose, R.P., Vogt, J.M., Paguntalan, L.M.J., Cariño, A.B., 2014. A survey of bats in a karst landscape in the central Philippines [WWW Document]. https://doi.org/info:doi/10.3161/150811014X683390

Simard, M., Pinto, N., Fisher, J.B., Baccini, A., 2011. Mapping forest canopy height globally with spaceborne lidar. J. Geophys. Res. Biogeosciences 116. https://doi.org/10.1029/2011JG001708

Simmons, N., Cirranello, A., 2020. Bat species of the World: A taxonomic and geographic database. [WWW Document]. URL https://batnames.org/ (accessed 2.8.21).

Simon, K.S., 2019. Chapter 26 - Cave ecosystems, in: White, W.B., Culver, D.C., Pipan, T. (Eds.), Encyclopedia of Caves (Third Edition). Academic Press, pp. 223-226. https://doi.org/10.1016/B978-0-12-814124-3.00025-X

Song, X.-P., Hansen, M.C., Stehman, S.V., Potapov, P.V., Tyukavina, A., Vermote, E.F., Townshend, J.R., 2018. Global land change from 1982 to 2016. Nature 560, 639-643. https://doi.org/10.1038/s41586-018-0411-9

Sonter, L.J., Ali, S.H., Watson, J.E.M., 2018. Mining and biodiversity: key issues and research needs in conservation science. Proc. R. Soc. B Biol. Sci. 285, 20181926. https://doi.org/10.1098/rspb.2018.1926

Souza Silva, M., Martins, R.P., Ferreira, R.L., 2015. Cave conservation priority index to adopt a rapid protection strategy: a case study in Brazilian Atlantic rain forest. Environ. Manage. 55, 279-295. https://doi.org/10.1007/s00267-014-0414-8

Srivastava, D.S., Cadotte, M.W., MacDonald, A.A.M., Marushia, R.G., Mirotchnick, N., 2012. Phylogenetic diversity and the functioning of ecosystems. Ecol. Lett. 15, 637-648. https://doi.org/10.1111/j.1461-0248.2012.01795.x

Sutherland, W.J., Broad, S., Butchart, S.H.M., Clarke, S.J., Collins, A.M., Dicks, L.V., Doran, H., Esmail, N., Fleishman, E., Frost, N., Gaston, K.J., Gibbons, D.W., Hughes, A.C., Jiang, Z., Kelman, R., LeAnstey, B., le Roux, X., Lickorish, F.A., Monk, K.A., Mortimer, D., Pearce-Higgins, J.W., Peck, L.S., Pettorelli, N., Pretty, J., Seymour, C.L., Spalding, M.D., Wentworth, J., Ockendon, N., 2019. A Horizon Scan of Emerging Issues for Global Conservation in 2019. Trends Ecol. Evol. 34, 83-94. https://doi.org/10.1016/j.tree.2018.11.001

Tanalgo, K.C., et al., 2021. DarkCideS 1.0, a global database for bats in karsts and caves. Authorea Preprints.

Tanalgo, K.C., Hughes, A.C., 2019. Priority-setting for Philippine bats using practical approach to guide effective species conservation and policy-making in the Anthropocene. Hystrix Ital. J. Mammal. 30, 74-83. https://doi.org/10.4404/hystrix00172-2019

Tanalgo, K.C., Tabora, J.A.G., Hughes, A.C., 2018. Bat cave vulnerability index (BCVI): A holistic rapid assessment tool to identify priorities for effective cave 
1173

1174

1175

1176

1177

1178

1179

1180

1181

1182

1183

1184

1185

1186

1187

1188

1189

1190

1191

1192

1193

1194

1195

1196

1197

1198

1199

1200

1201

1202

1203

1204

1205

1206

1207

1208

1209

1210

1211

1212

1213

1214

1215

conservation in the tropics. Ecol. Indic. 89, 852-860.

https://doi.org/10.1016/j.ecolind.2017.11.064

The World Bank, 2020. Forest area (\% of land area) | Data [WWW Document]. URL https://data. worldbank.org/indicator/AG.LND.FRST.ZS?end=2016\&start=1990\&vi ew=chart (accessed 10.16.20).

Theobald, E., Hosken, D.J., Foster, P., Moyes, K., 2020. Mines and bats: the impact of open-pit mining on bat activity [WWW Document]. https://doi.org/10.3161/15081109ACC2020.22.1.014

Torres-Flores, J.W., Santos-Mreno, A., 2017. Inventory, features, and protection of underground roosts used by bats in Mexico [WWW Document]. https://doi.org/info:doi/10.3161/15081109ACC2017.19.2.019

Trimble, M.J., Aarde, R.J.V., 2010. Species Inequality in Scientific Study. Conserv. Biol. 24, 886-890. https://doi.org/10.1111/j.1523-1739.2010.01453.x

UNEP/EUROBATS, 2020. UNEP/EUROBATS | Agreement on the Conservation of Populationsof European Bats [WWW Document]. URL https://www.eurobats.org/ (accessed 2.6.21).

Vos, J.M.D., Joppa, L.N., Gittleman, J.L., Stephens, P.R., Pimm, S.L., 2015. Estimating the normal background rate of species extinction. Conserv. Biol. 29, 452-462. https://doi.org/10.1111/cobi.12380

Welch, J.N., Beaulieu, J.M., 2018. Predicting Extinction Risk for Data Deficient Bats. Diversity 10, 63. https://doi.org/10.3390/d10030063

Whitten, T., 2009. Applying ecology for cave management in China and neighbouring countries. J. Appl. Ecol. 46, 520-523. https://doi.org/10.1111/j.13652664.2009.01630.x

Wilson, K.A., Underwood, E.C., Morrison, S.A., Klausmeyer, K.R., Murdoch, W.W., Reyers, B., Wardell-Johnson, G., Marquet, P.A., Rundel, P.W., McBride, M.F., Pressey, R.L., Bode, M., Hoekstra, J.M., Andelman, S., Looker, M., Rondinini, C., Kareiva, P., Shaw, M.R., Possingham, H.P., 2007. Conserving Biodiversity Efficiently: What to Do, Where, and When. PLOS Biol. 5, e223. https://doi.org/10.1371/journal.pbio.0050223

Wintle, B.A., Kujala, H., Whitehead, A., Cameron, A., Veloz, S., Kukkala, A., Moilanen, A., Gordon, A., Lentini, P.E., Cadenhead, N.C.R., Bekessy, S.A., 2019. Global synthesis of conservation studies reveals the importance of small habitat patches for biodiversity. Proc. Natl. Acad. Sci. 116, 909-914. https://doi.org/10.1073/pnas.1813051115

Yamazaki, D., Trigg, M.A., Ikeshima, D., 2015. Development of a global 90m water body map using multi-temporal Landsat images. Remote Sens. Environ. 171, 337-351. https://doi.org/10.1016/j.rse.2015.10.014

Zamora-Gutierrez, V., Amano, T., Jones, K.E., 2019. Spatial and taxonomic biases in bat records: Drivers and conservation implications in a megadiverse country. Ecol. Evol. 9, 14130-14141. https://doi.org/10.1002/ece3.5848 
A
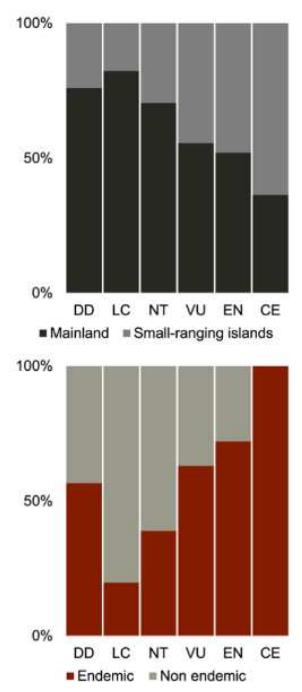

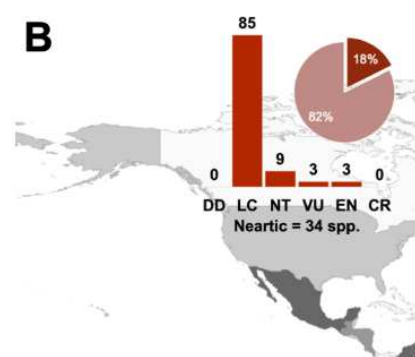

Estimated species richness

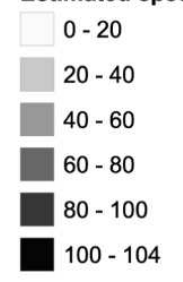

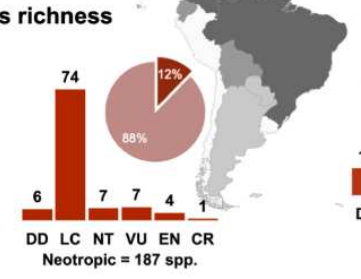

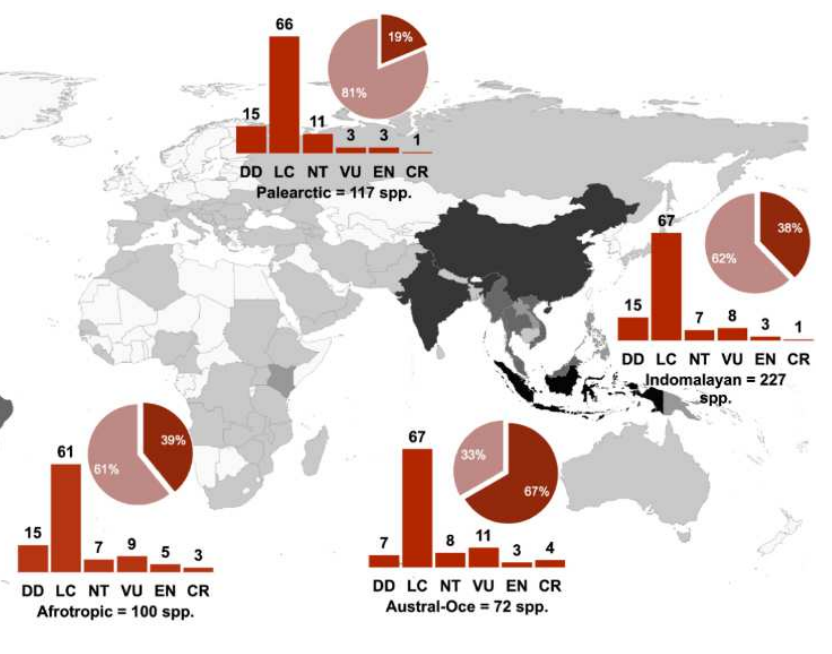

Figure 1. Species diversity and distribution of cave-dwelling bats. IUCN-based conservation status according to (a) country and island endemism, and (b) taxonomic distribution of estimated species richness of cave bats per country, and proportion of endemic species (in pie graph) and threatened (in the bar graph) of compared by biogeographical realm. The proportion of country endemic species differed regionally $\left(\chi^{2}\right.$ $=93.49, d f=5, P<0.0001)$ and is highest in the Indomalayan region $(38 \%, N=86$ spp.). The highest number of nationally endemic species was recorded in Madagascar $(N=23$ spp., $\%$ endemism $=82 \%)$, Indonesia $(N=21$ spp., $\%$ endemism $=20 \%)$, and Australia $(N=18$ spp., $\%$ endemism $=55 \%)$ (See also Data S2). 


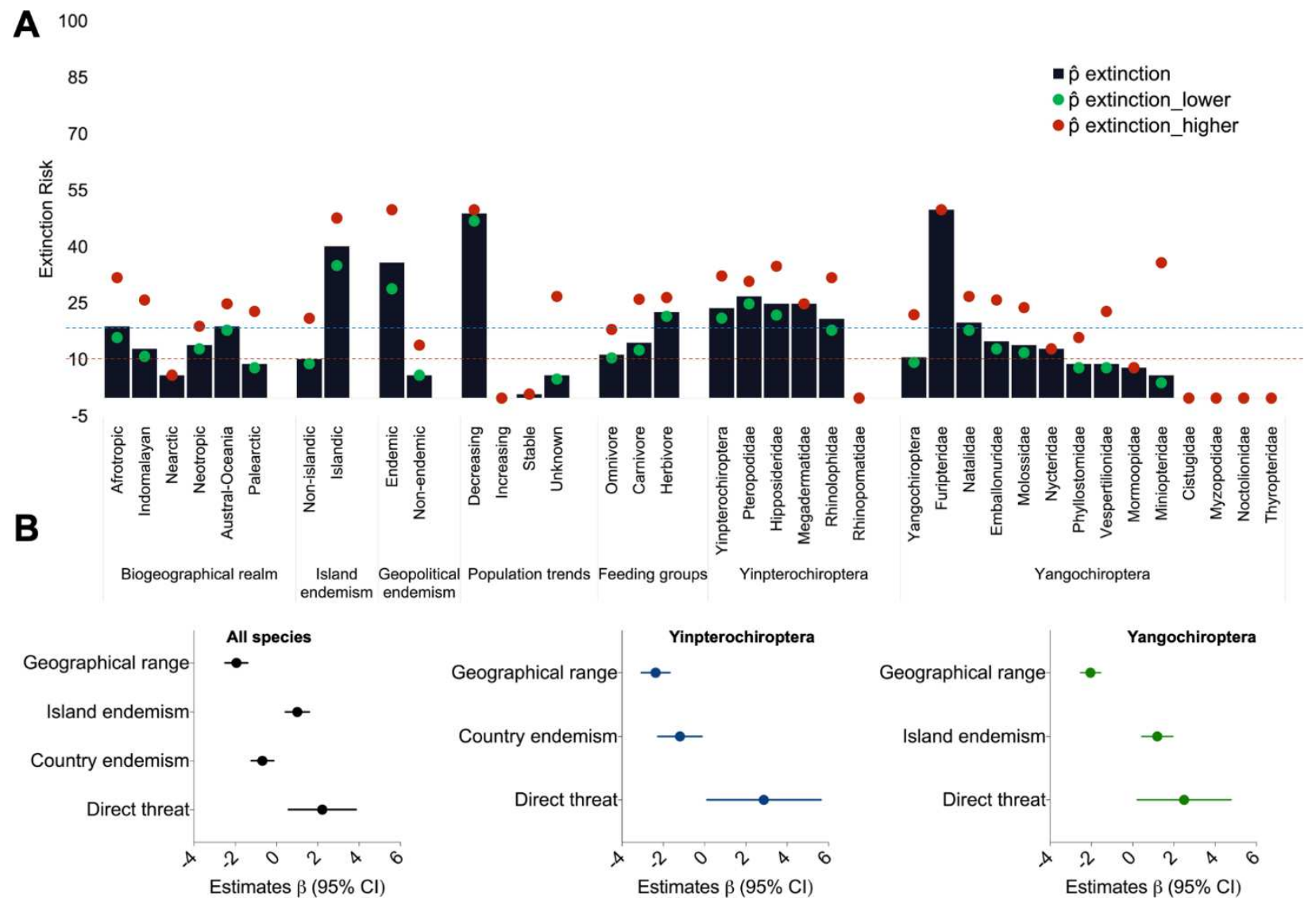

Figure 2. IUCN-based extinction risk. (a) Estimated extinction risks ( $\hat{p}$ extinction) of global cave-dwelling bat species compared by biogeographical realm, island endemism, geopolitical endemism, population trends, trophic groups, sub-orders and families. Estimated extinction proportion ( $\hat{p}$ extinction) for global species (blue dashed line) and all cave-dwelling bats (red dashed line) is provided. All computed values are supplemented in Table S2. (B) Estimate coefficients of significant determinants extinction risks of all global species, and amongst suborders Yinpterochiroptera and Yangochiroptera. Summary of binomial generalised linear mixed (GLMs) explaining species extinction risks is provided in Table S3. 
A

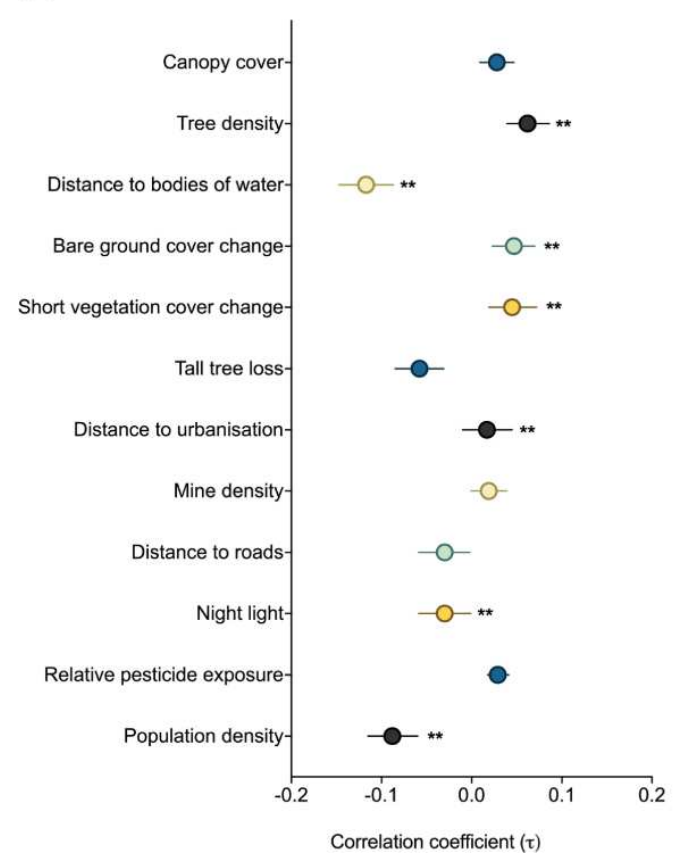

B

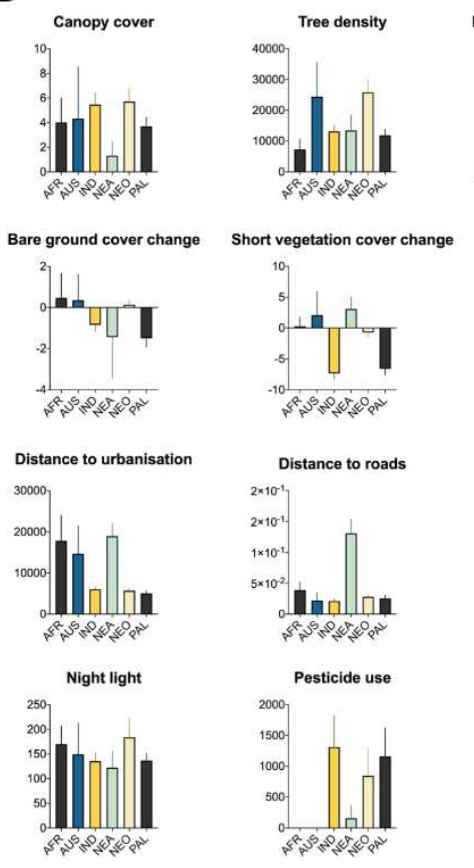

C

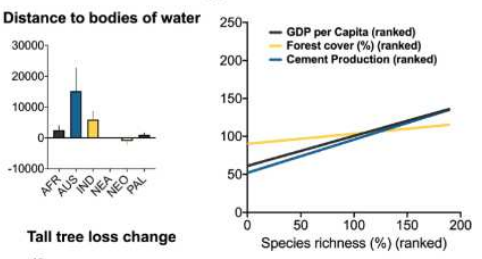

Tall tree loss change
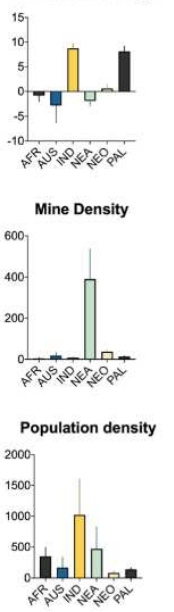
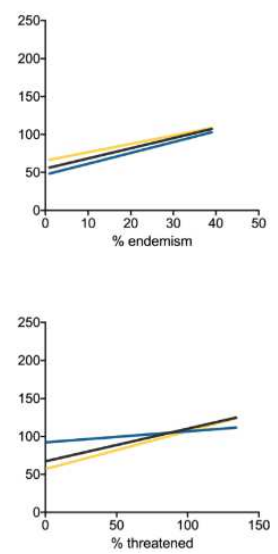

1243 Figure 3. Relationship, extent, and distribution of threats amongst assessed landscape features and threats and species cave biotic scores, (b) biogeographic comparison of mean intensity of vulnerabilities to landscape features and threats. When compared regionally, the mean intensity of landscape features and threat variables differed significantly except for relative exposure to pesticide. Bat caves in the Afrotropical, Austral-Oceania and Nearctic regions showed the highest vulnerability to distance to urban areas. While Nearctic caves showed the nearest distance to roads and the highest mapped mine density. The mean proportion of bare ground cover change is low in arid regions of the Afrotropical and Austral-Oceania. Whereas population density and relative pesticide exposure are exceedingly high in Indomalayan caves, highlighting potentially high deforestation and loss of natural habitats. (c) Global concordance of between country socioecological indicators (country GDP, Forest cover, cement export production) and species attributes (up to down: country species richness, endemism, and proportion of threatened species). (values with ** showed significance at $P<0.05$ ). 
A
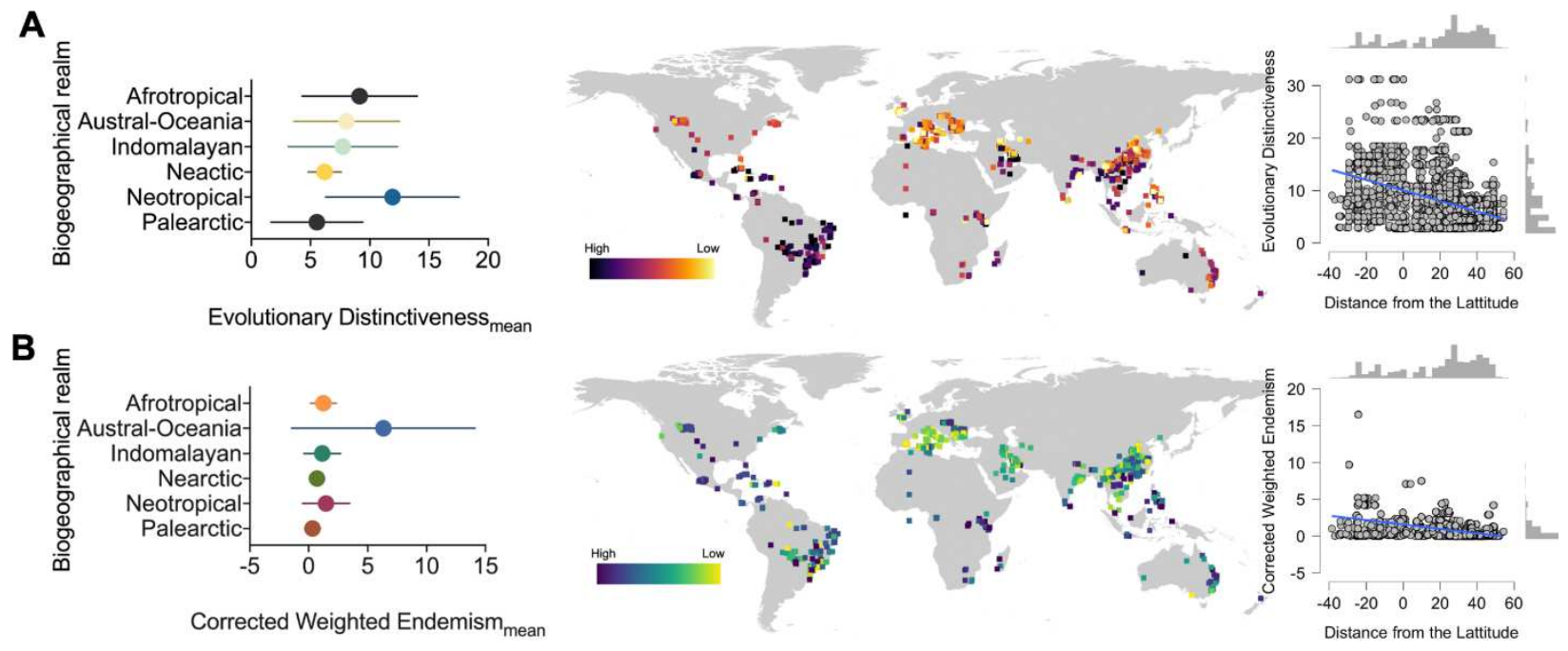
1260 Figure 4. Comparison of bat cave evolutionary distinctiveness (A) and endemism (B)
1261 across biogeographical realm and the latitudinal relationship of ED and CWE (right). 

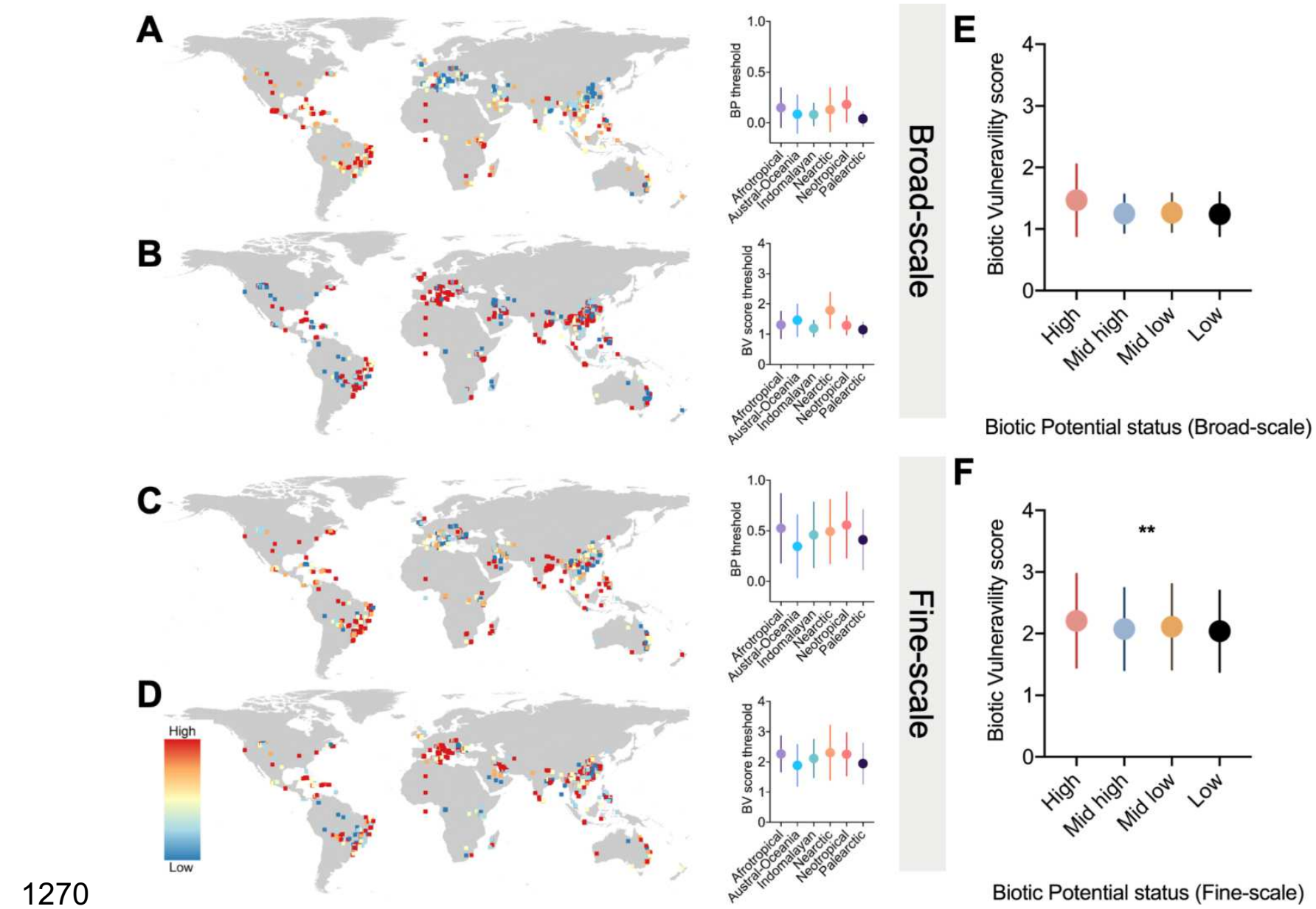

Figure 5. Distribution and relationships of cave biotic potential and vulnerability worldwide. Broad-scale (A) Biotic Potential (BP), (B) Biotic Vulnerability (BV); and Finescale (C) Biotic Potential (BP), and (D) Biotic Vulnerability (BV)) (All values significantly differed; error bar represents mean $\pm S D$ ). (E-F) relationship of cave Biotic Potential status to Biotic Vulnerability scores compared in both broad-scale and fine-scale analyses (values with ${ }^{* *}$ showed significance at $P<0.05$; error bars represent mean \pm 1277 $\mathrm{SD})$. 


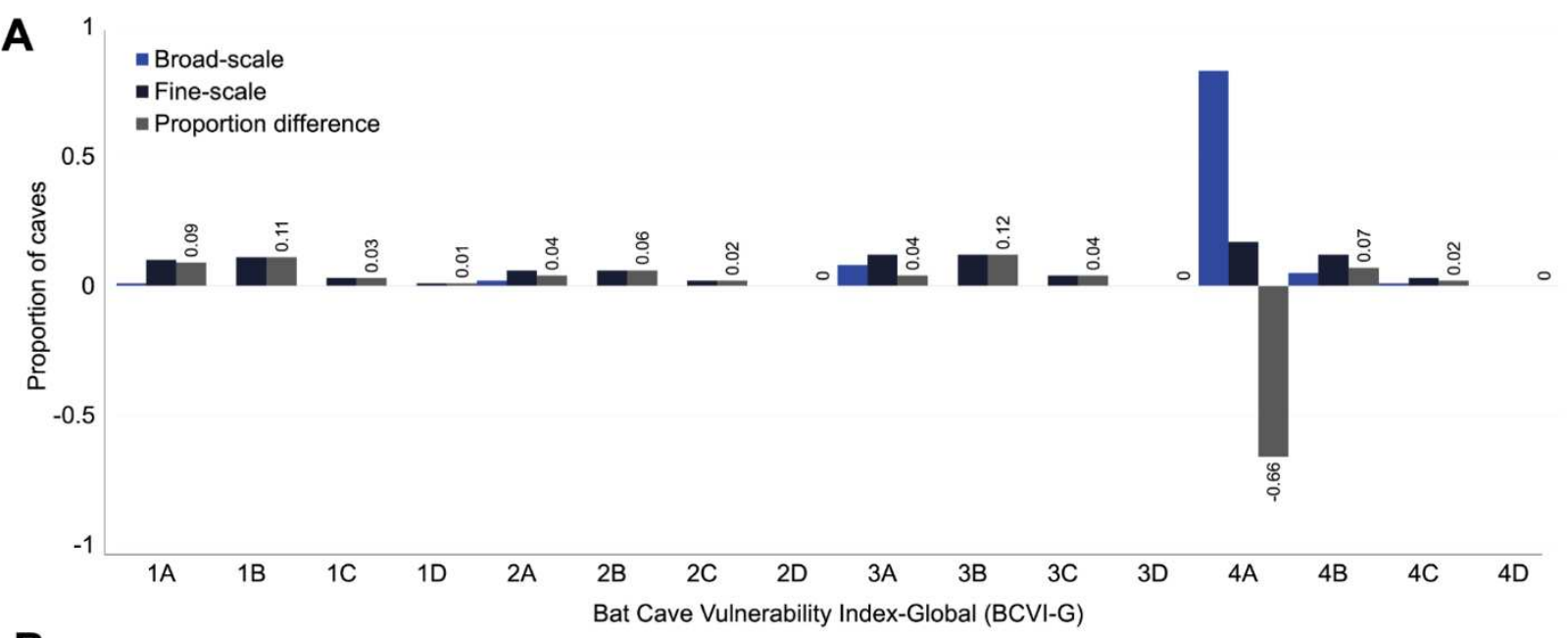

B

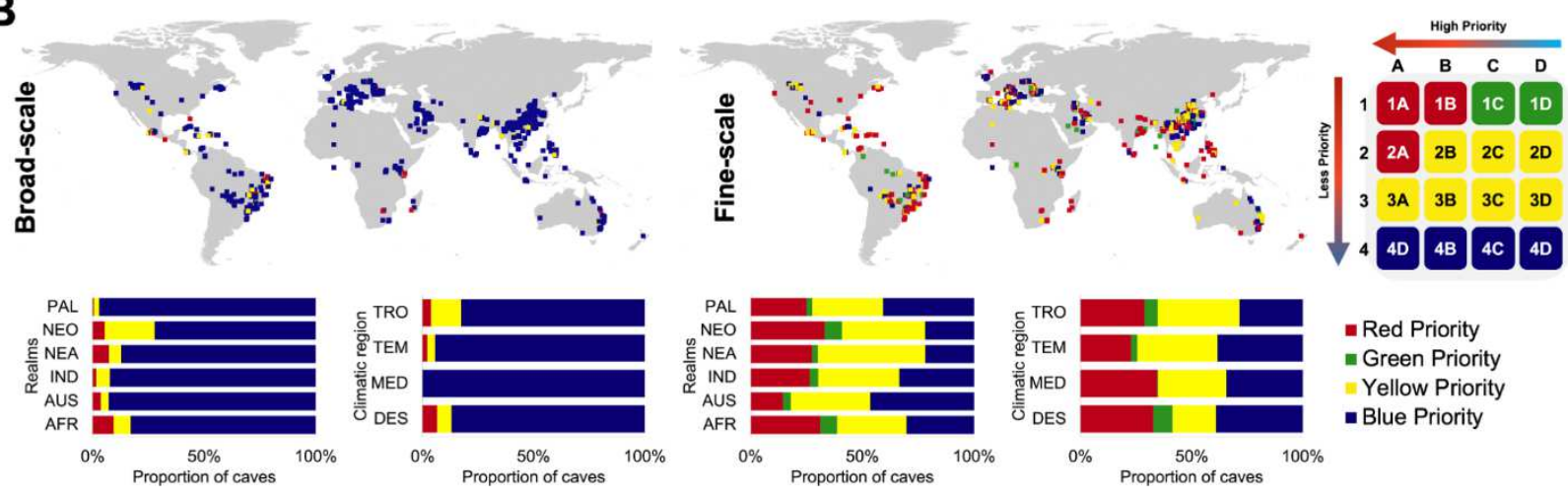

Figure 6. Global Bat Cave Vulnerability Index and Priorities. (a) Proportion and proportion differences of cave Bat Cave Vulnerability Index- Global (BCVI-G) analysed in broad-scale and fine-scale. The number and percentage of caves according to BCVIG scales is supplemented in Data S3. Spatial conservation priorities in (b) broad-scale and fine-scale based on Bat Cave Vulnerability Index- Global (BCVI-G). Broad-scale shows poor performance in showing high priority caves compared to fine-scale prioritisation. Proportions are compared across biogeographical realms and climatic regions. Summaries BCVI-G based priorities are being supplemented in Table S6. 
1298

1299

1300

1301

1302

1303

1304

1305

1306

1307

1308

1309

1310

1311

1312

1313

1314

1315

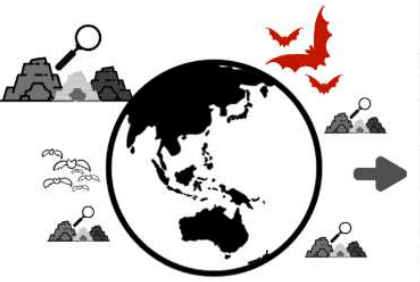

Globally-pooled cave sites

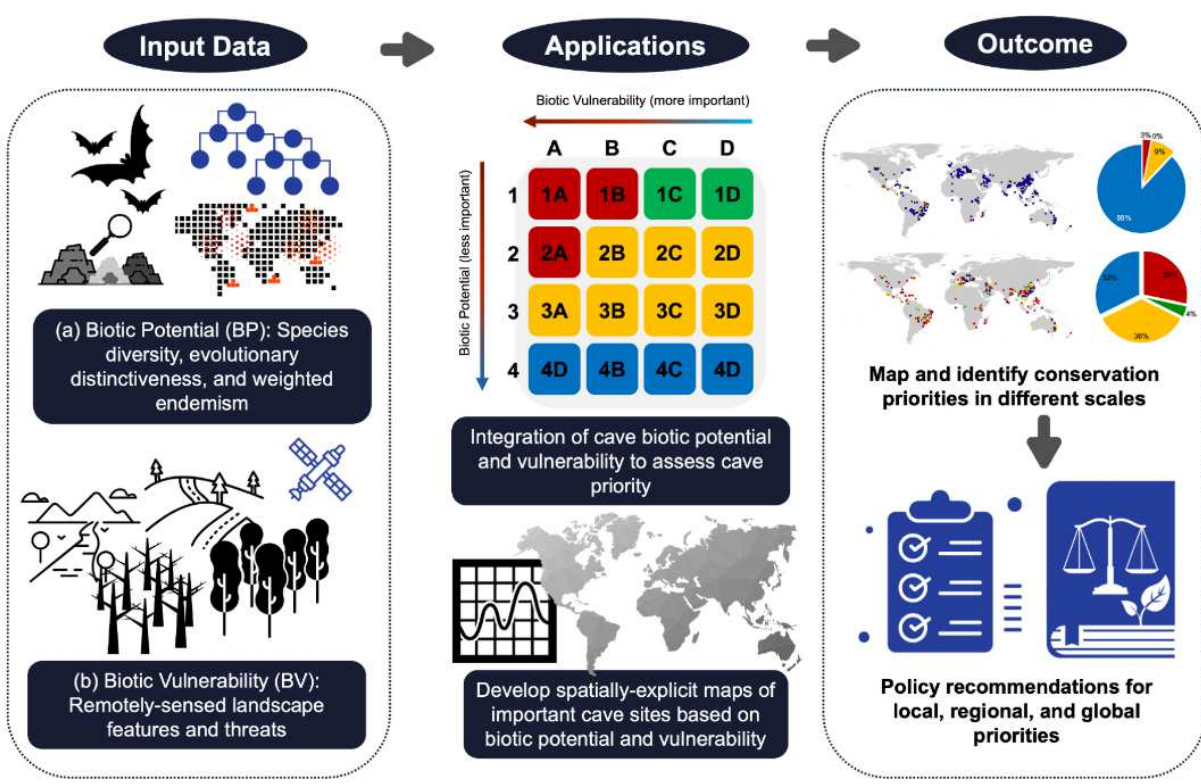

Figure 7. Framework for prioritising bat caves for conservation. The schematic diagram showing the frame of the Bat Cave Vulnerability Index-Global (BCVI) in identifying and setting priorities for bat caves for conservation on a global scale. The process starts with the pooling of caves sites for assessment assess cave priorities. The input data includes the bat cave diversity (BP) and remotely senses landscape features to assay threats (BV). The index is categorised in four (4) levels with red caves are high priority sites containing the highest diversity and threats and requires immediate conservation actions, while blue caves are the lowest priority sites with the least biodiversity and high to low threat, but no immediate conservation attention is needed. 
1317 Data S1. Complete list of cave-dwelling bat species pooled from the International Union for the Conservation of Nature Red List (IUCN Red List) version 2020. The supplementary dataset contains complete taxonomic information, habitat preference, biogeographical range, species distribution, conservation status, endemism, ecological traits, and threatening process.

Data S2 Country-level species diversity of cave-dwelling bats including estimated species richness, endemism, and proportion of threatened species. The supplementary data also contains the country-level socioecological status including the rate of cement production, forest cover (\%), and country Gross Domestic Production (GDP).

1326 Data S3. Complete list of cave sites and species diversity analysed for prioritisation using Bat Cave Vulnerability Index-Global (BCVI-G). The results of BCVI-G prioritisation in broad-scale and fine-scale are also provided.

1329 Figure S1. Supplementary Figure 2. Distribution of global dominant threats $(A)$ and biogeographical patterns (frequency) of the threatening process (B) and mean threat index (C). Complete threat distribution per species is supplemented in Supplementary Data 1.

Figure S2. Effects of geographic range, adult body mass, trophic group and island endemism on species risks to key threatening process. Complete results of the models are supplemented in Supplementary Table 4.

1336 Table S1. Distribution of conservation status across families.

Table S2. Extinction risks of cave-dwelling bats across different taxonomic and ecological 1338 dimensions

1339 Table S3. Summary of Binomial Generalised Linear Mixed (GLMs) explaining species extinction risk of (A) global species, and in between suborders (B) Yinpterochiroptera, 1341 and (C) Yangochiroptera.

1342 Table S4. Summary of threatening process across the biogeographical realm and 1343 Species Threat Index (SPI) in each ecological dimension.

1344 Table S5. Summary statistics of Generalised Linear Models (GLM) predicting the 1345 1346

1347 Table S6. Distribution (cave count) of BCVI in broad-scale and fine-scale across 1348 Biogeographical realm and climatic regions. 


\section{Supplementary Files}

This is a list of supplementary files associated with this preprint. Click to download.

- Figures1.docx

- Figures2.docx

- Tables1.docx

- Tables2.docx

- TableS3.docx

- TableS4.docx

- Tables5.docx

- TableS6.docx

- DataS1.xlsx

- DataS2.xlsx

- DataS3.xlsx 